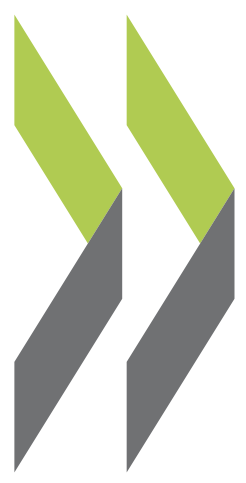

OECD Economics Department Working Papers No. 1144

Women's Role in the Swiss

Economy

\author{
Richard Dutu
}

https://dx.doi.org/10.1787/5jz123dzstkb-en 


\section{Unclassified}

ECO/WKP(2014)40

Organisation de Coopération et de Développement Économiques

Organisation for Economic Co-operation and Development

15-Jul-2014

ECONOMICS DEPARTMENT

English - Or. English

WOMEN'S ROLE IN THE SWISS ECONOMY

ECONOMICS DEPARTMENT WORKING PAPERS No. 1144

\section{By Richard Dutu}

OECD Working Papers should not be reported as representing the official views of the OECD or of its member countries. The opinions expressed and arguments employed are those of the author.

Authorised for publication by Alvaro Pereira, Director, Country Studies Branch, Economics Department.

All OECD Economics Working Papers are available through OECD's Internet website at: www.oecd.org/eco/workingpapers

JT03360448

Complete document available on OLIS in its original format

This document and any map included herein are without prejudice to the status of or sovereignty over any territory, to the delimitation of international frontiers and boundaries and to the name of any territory, city or area. 


\section{$\mathrm{ECO} / \mathrm{WKP}(2014) 40$}

OECD Working Papers should not be reported as representing the official views of the OECD or of its member countries. The opinions expressed and arguments employed are those of the author.

Working Papers describe preliminary results or research in progress by the authors and are published to stimulate discussion on a broad range of issues on which the OECD works.

Comments on Working Papers are welcomed, and may be sent to OECD Economics Department, 2 rue André-Pascal, 75775 Paris Cedex 16, France, or by e-mail to eco.contact@oecd.org

This document and any map included herein are without prejudice to the status of or sovereignty over any territory, to the delimitation of international frontiers and boundaries and to the name of any territory, city or area.

The statistical data for Israel are supplied by and under the responsibility of the relevant Israeli authorities. The use of such data by the OECD is without prejudice to the status of the Golan Heights, East Jerusalem and Israeli settlements in the West Bank under the terms of international law.

You can copy, download or print OECD content for your own use, and you can include excerpts from OECD publications, databases and multimedia products in your own documents, presentations, blogs, websites and teaching materials, provided that suitable acknowledgment of OECD as source and copyright owner is given. All requests for commercial use and translation rights should be submitted to rights@oecd.org. 
ECO/WKP(2014)40

\section{ABSTRACT/RÉSUMÉ \\ Women's role in the Swiss economy}

Swiss women are now as well educated as their male counterparts. However, progress remains to be made in the job market where both the supply and price of female labour are below that of men. While the participation rate for women is high and rising, it is offset by a heavy incidence of part-time work, reflecting both personal preferences and factors that limit their labour supply. The lack and high cost of childcare options for parents, as well as burdensome marginal income tax rates for second earners, create disincentives to work more. A falling but persistent net (i.e. unexplained) wage gap of about $7 \%$ in favour of men, coupled with under-representation of women as managers and entrepreneurs, further reduce the incentive for women to take full advantage of their high levels of human capital. Priority should be given to removing those barriers by increasing public spending on childcare and out-of-school-hours care at the cantonal and municipal levels. Existing regulations regarding childcare provision should also be investigated to see whether a broader range of price and quality childcare options is feasible. The implicit tax penalty for married women should also be removed, as the Federal Council is currently considering. More flexibility in working arrangements could further alleviate women's cost of reconciling work and family life. For instance, facilitating flexi-time, annualised hours, job-sharing, part-time and telework options for both women and men, and creating paternity and/or consecutive, take-it-or-leave-it parental leave could facilitate transition in and out of the labour market. Increasing competition in product markets should help reduce the wage gap by replacing old habits with the hunt for talent regardless of gender. Finally, a corporate governance code in favour of a more equal representation of women in leadership positions, and setting ambitious quantitative targets for women on boards combined with the "Comply or Explain" practise, or quotas, should help remove the so-called glass ceiling. This Working Paper relates to the 2013 OECD Economic Review of Switzerland (www.oecd.org/eco/surveys/Switzerland).

JEL classification codes: H5; I2; J16; J2; J3

Keywords: Switzerland, gender, education, labour market, wage gap, leadership

\section{Le rôle des femmes dans l'économie suisse}

En Suisse, les femmes ont désormais un niveau de formation égal à celui des hommes. Néanmoins, des progrès restent à accomplir sur le marché du travail où l'offre de main-d'œuvre féminine et sa rémunération sont inférieures à celles des hommes. Le taux d'activité des femmes est élevé et ne cesse de croître, ce qui est contrebalancé toutefois par une forte incidence du travail à temps partiel, reflet de préférences individuelles et de facteurs qui restreignent le travail des femmes. L'insuffisance et le coût élevé des solutions de garde des enfants, conjugués à un taux marginal d'imposition important pour les deuxièmes apporteurs de revenus, dissuadent les femmes de travailler plus. L'écart net (c'est-à-dire inexpliqué) de rémunération de $7 \%$ environ en faveur des hommes, persistant quoiqu'en baisse, n'incite pas non plus les femmes à tirer pleinement profit de leur niveau de formation élevé, d'autant qu'elles sont sous-représentées parmi les dirigeants et les chefs d'entreprise. Il faut donc éliminer ces obstacles en priorité, en augmentant les dépenses publiques consacrées aux structures de garde de jeunes enfants et d'accueil en dehors des heures d'école à l'échelon des cantons et des communes. Il faudrait aussi étudier la réglementation actuellement applicable aux services de garde d'enfant pour voir s'il est possible d'élargir la gamme des prestations offertes, en termes de tarifs et de qualité. Il convient également de supprimer l'effet pénalisant implicite du mariage sur le plan fiscal, comme cela est actuellement envisagé par le Conseil Fédéral. Une plus grande flexibilité dans l'aménagement du temps de travail pourrait également permettre aux femmes de concilier travail et vie de famille. Ainsi, offrir aux femmes comme aux hommes la possibilité d'opter plus facilement pour des solutions comme les horaires de travail flexibles, l'annualisation des horaires, le partage de poste, le temps partiel ou le télétravail, et instituer un congé paternité et/ou un congé parental consécutif unique et non transférable pourraient aider les femmes à intégrer le marché du travail et à en sortir plus aisément. Le renforcement de la concurrence sur les marchés de produits devrait contribuer à combler l'écart de rémunération entre hommes et femmes, en remplaçant notamment certaines pratiques discriminatoires par la recherche des meilleurs talents, indépendamment du sexe. Enfin, un code de gouvernement d'entreprise en faveur d'une représentation plus égalitaire des femmes aux postes de direction et la fixation d'objectifs ambitieux pour accroître la proportion de femmes dans les conseils d'administrations, conjugués à l'adoption du modèle " appliquer ou expliquer », ou encore l'instauration de quotas, devraient faciliter la disparition du «plafond de verre ». Ce Document de travail se rapporte à l'Étude économique de l'OCDE de la Suisse 2013 (www.oecd.org/eco/etudes/Suisse).

Classification JEL : H5; I2; J16; J2; J3

Mots clefs : Suisse, genre, éducation, marché du travail, écart salarial, cadre 


\section{Table of contents}

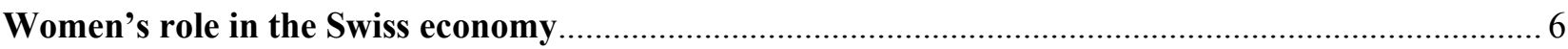

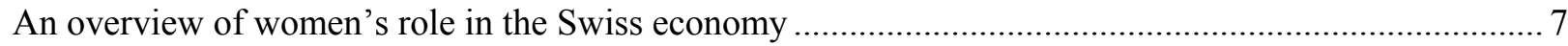

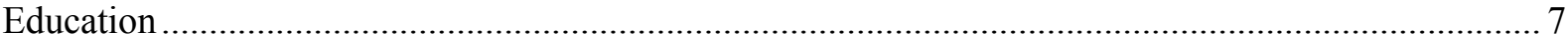

Labour market.

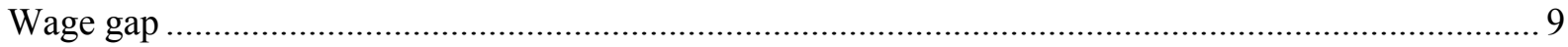

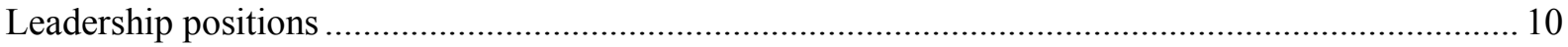

Education: overall equality in attainment, but gender differences in subject studied .............................. 10

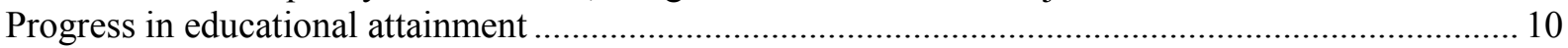

Progress supported by high expectations and a fair level of financial support..................................... 14

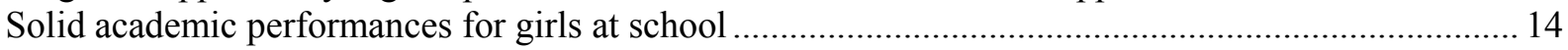

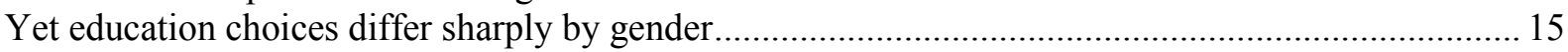

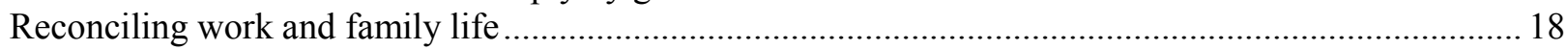

A strong presence on the labour market not in proportion with the volume of hours worked .............. 18

Labour market outcomes reflect education choices and constraints................................................. 20

The lack of a family-friendly working environment forces women to make difficult choices.............. 22

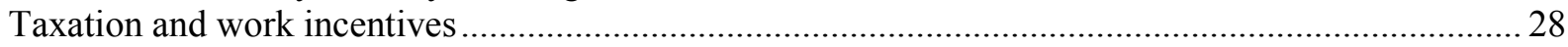

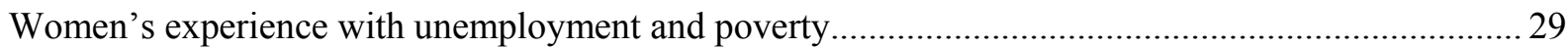

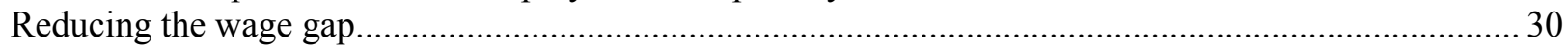

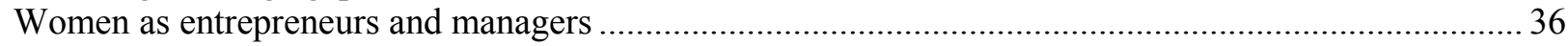

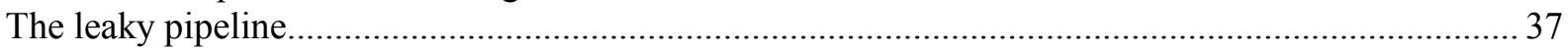

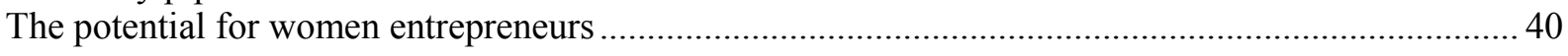

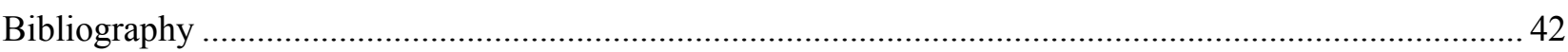

\section{Boxes}

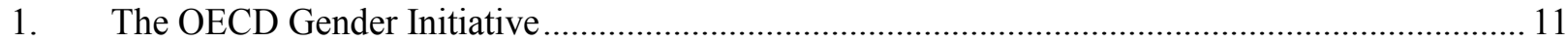

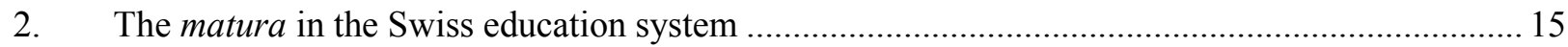

3. What determines gender differences in subject choice? A selected survey ................................. 17

4. Recommendations to make the education system more gender balanced ..................................... 18

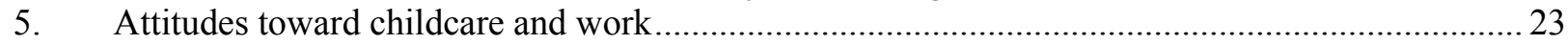

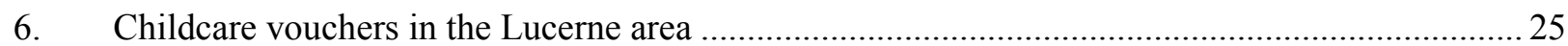

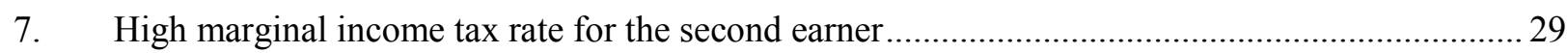

8. Recommendations for a better reconciliation between work and family life ............................... 30

9. Does wage discrimination start right after school? Data from the TREE study ............................. 33

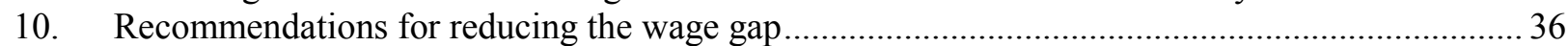

11. The effect of gender-diverse boards on governance and performance: mixed evidence................ 37

12. How to succeed without quotas? The Swedish example .......................................................... 39

13. Recommendations for removing the glass ceiling and encouraging entrepreneurship among

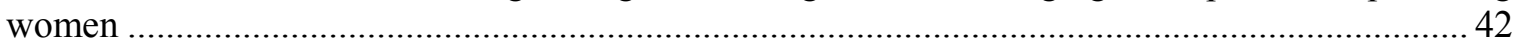




\section{Tables}

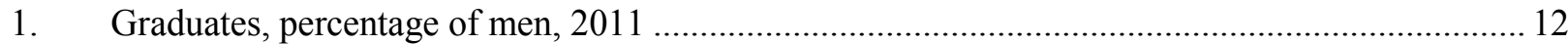

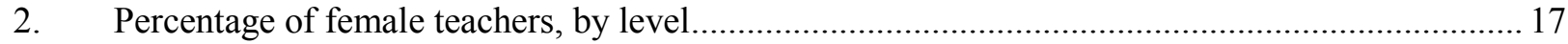

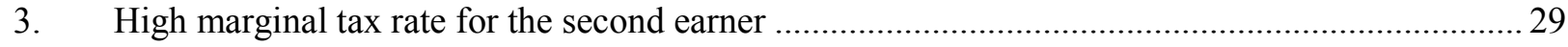

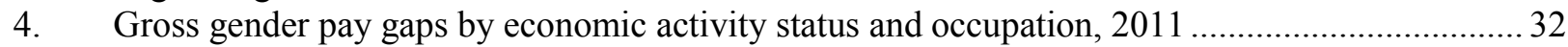

\section{Figures}

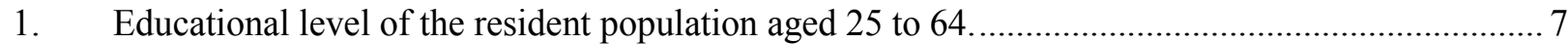

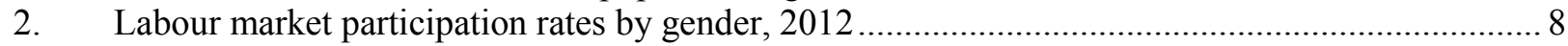

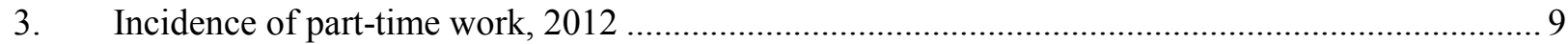

4. Gender gap in median earnings of full-time equivalent employees, 2011 ..................................9

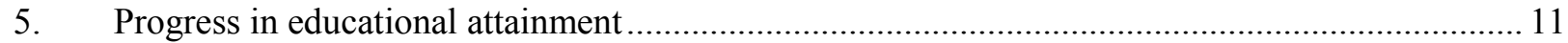

6. Percentage of female students, by level of education, 1996-2010 ............................................. 12

7. Entry and graduation rates in non-vocational tertiary education by gender ................................. 13

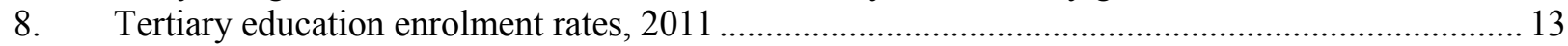

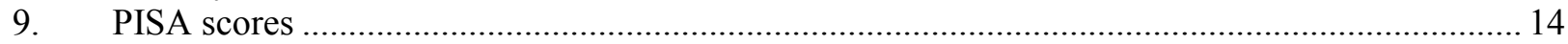

10. Evolution of the percentage of women in matura, by type....................................................... 15

11. Degrees awarded in universities of applied sciences by gender ............................................ 16

12. Percentage of females among teachers, by level of education .............................................. 17

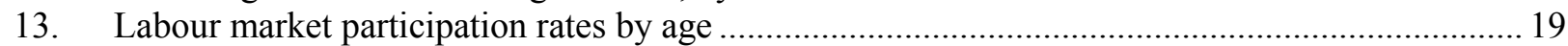

14. Female employment rate for those aged 15 to 64 and workforce composition............................ 19

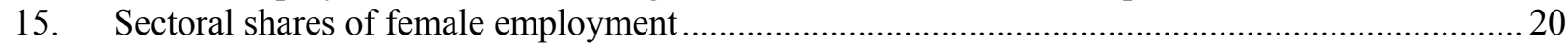

16. Employment in R\&D activities in Switzerland, by sector and gender .................................... 21

17. Relative earnings for those aged 25-64 with tertiary education ............................................. 21

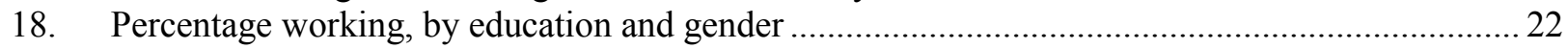

19. Tensions between work and family life are central to child-bearing decisions............................ 22

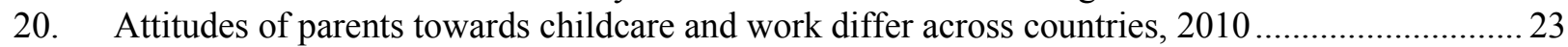

21. Public spending on childcare and pre-primary education, 2009............................................. 24

22. Number of childcare facilities per 1000 children less than 7 years old by canton .....................25

23. Out-of-pocket childcare costs for a couple family: full-time care at a typical childcare centre.....26

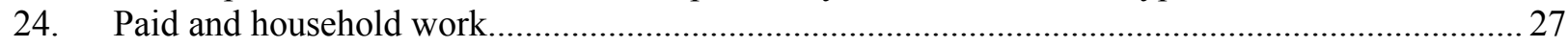

25. Percentage contribution to total household income, by type of household .................................... 28

26. Women's unemployment is higher, but men's is more responsive to business fluctuations........... 30

27. Difference between men and women's wages (gross gap)................................................. 31

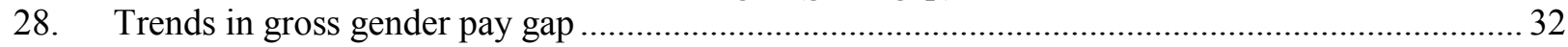

29. Employed persons by brackets of annual gross employment income in francs, 2011 ..................33

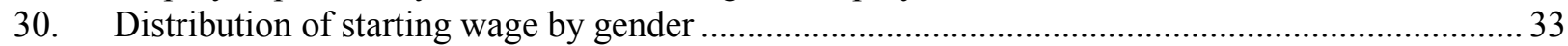

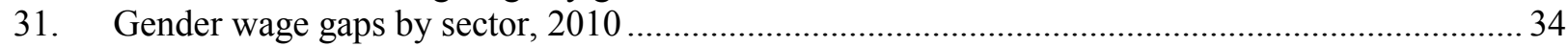

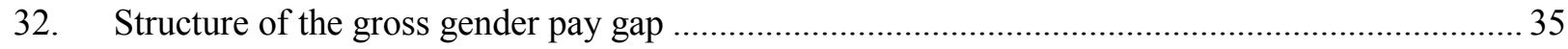

33. Unexplained share in gender wage gap, or net gap ................................................................ 36

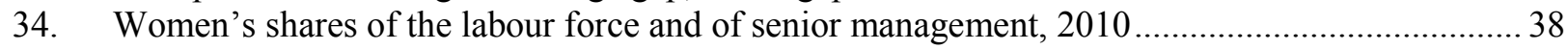

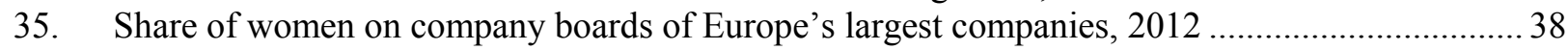

36. Swiss women have fostered their presence in political institutions.......................................... 40

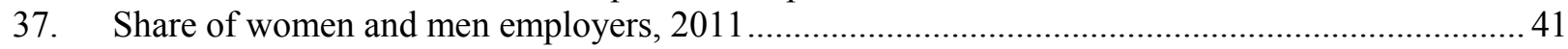

38. Three-year survival rate of men and women-owned enterprises ............................................. 41

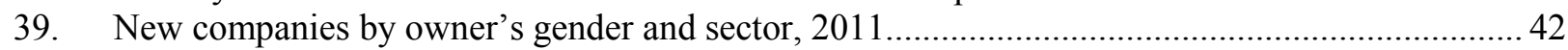




\title{
Women's role in the Swiss economy
}

\author{
By \\ Richard Dutu ${ }^{1}$
}

Switzerland has a high-performing economy. It ranks fourth in terms of GDP per capita in the OECD, regularly places among the best countries in terms of quality of life and is one of the few Western European countries that has managed to grow over the past few years. However, Switzerland suffers from a number of weaknesses that prevent it from doing even better. One is the country's relatively modest longer-term productivity growth performance. In this article it is argued that making fuller use of the economic potential of Swiss women can be part of the solution. With women providing a large reserve of highly educated labour, increasing their role in the economy can help Switzerland close the multifactor productivity (MFP) gap with frontier OECD countries.

Gender equality is also a key driver of self-reported well-being and happiness (Veenhoven, 2011 and 2012). But promoting gender equality is not only about equity and well-being; it is also about economic performance. Greater gender equality in economic and educational opportunities increases long-term growth potential and contributes to a better allocation of human capital across occupations. Raising women's education and training enhances their skill set. Increasing their participation in the labour market boosts their experience and leadership abilities. It also empowers women and favours entrepreneurial risk taking. At the macroeconomic level, a greater role for women increases the government's return on educational investment and its tax take.

Women's role in developed nations' economies has changed significantly since the end of World War II. From being mostly occupied at home, women have joined the workforce in great numbers. In parallel their average level of education has increased significantly to a point where more women than men are now attending universities in many OECD countries. In spite of such progress, there are still areas where women are missing out on opportunities to do as well as men, especially in the labour market.

Switzerland is no exception to this picture, both in terms of progress and challenges. Regarding the former, the principle of gender equality has been part of the Federal Constitution since 1981, and in 1988 the Federal Office for Gender Equality was established. In 1996, the Federal Act on Gender Equality came into force. It focuses on equality in employment relationships and prohibits any form of discrimination of

1. Richard Dutu is an economist in the Country Studies Branch of the Economics Department of the OECD; e-mail: richard.dutu@oecd.org. This paper was prepared for the OECD Economic Survey of Switzerland published in November 2013 under the authority of the Economic and Development Review Committee. The author is thankful to Willem Adema, Doris Aebi, Max Bergman, Hansjörg Blöchliger, Monika Bütler, Somali Cerise, Andrew Dean, Gaëlle Ferrant, Robert Ford, Jens-Christian Hoj, Peter Jarrett, Bruno Jeitziner, Anne Küng Gugler, Brigitte Liebig, Mario Piacentini, Peter Vujanovic, Gabrielle Wanzenried, and Swiss government officials for their valuable comments and suggestions. Special thanks are due to Patrizio Sicari for excellent statistical assistance and Mee-Lan Frank for technical preparation. 
men and women based on their sex, including wage discrimination. In the 2013 Global Gender Gap Report (from the World Economic Forum, 2013) Switzerland ranked $9^{\text {th }}$ out of 136 countries. Nevertheless, women in Switzerland are held back by a number of hurdles in the labour market - some specific to Switzerland, and some not - and by difficulties associated with reconciling work and family life.

After an overview of women's role in the Swiss economy, achievements and challenges in four key areas of economic life are reviewed. The first section focuses on education and examines how girls compare to boys in terms of attainment, opportunities and study choices. The next looks at the labour market, the transition from school to the workplace and the difficulties that women face in trying to reconcile their professional skills with their family life. A subsequent section is devoted to the gender wage gap and how it can be reduced. The final part examines how Swiss women are faring regarding access to management, leadership positions and entrepreneurial activities. At the end of each section (education, work and family life, wage gap and leadership/entrepreneurship) policy recommendations are formulated.

\section{An overview of women's role in the Swiss economy}

Both the supply of female labour and its price are lower than that of men. While any remaining gap has disappeared in education, Swiss women are overwhelmingly working part-time, in classical female occupations, and are significantly under-represented as managers, board members and entrepreneurs. Controlling for observable differences, the wage gap has fallen steadily albeit slowly as women's wages have increased faster than men's in all but one of the last five decades. The net wage gap now sits at about $7 \%$ in favour of men, which to some extent may be attributed to gender discrimination.

\section{Education}

Switzerland has a highly educated female workforce. The average expected years of schooling is now the same for men and women, and since 2009 more women than men have been enrolling in tertiary general education. This progress has led to a more symmetric distribution of educational levels across the resident population, although the past still plays a role. For instance, proportionally more women than men have received no more than secondary education in the $25-64$ age bracket: $70 \%$ versus $57 \%$ (Figure 1).

Figure 1. Educational level of the resident population aged 25 to 64

2012

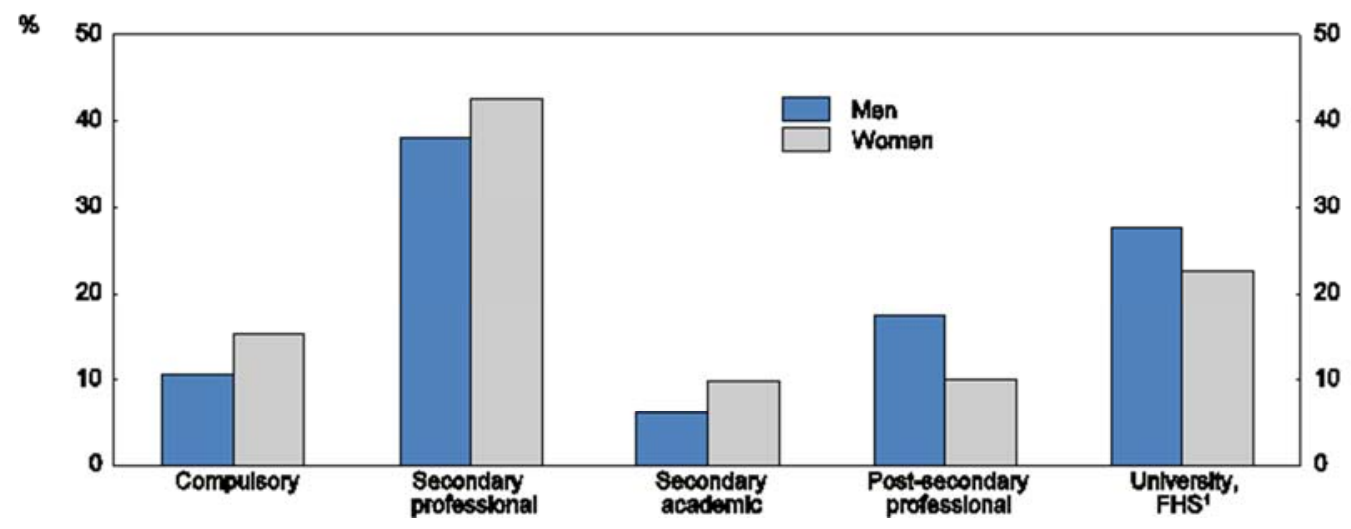

Note: FHS=Fachhochschulen

Source: FSO. 


\section{Labour market}

The Swiss female labour market is characterised by two major traits. On the one hand the female participation rate is very high at $78.5 \%$ (the OECD average is $63.9 \%$ ), the third highest in OECD (Figure 2). On the other their incidence of part-time work (part-time employment as a proportion of total employment) is $45 \%$, second only to the Netherlands at $60 \%$ and well above the OECD average of $27 \%$ (Figure 3). It is worth noting that the part-time share for Swiss women has risen significantly from $49.2 \%$ to $58.5 \%$ over the last 20 years, while for men it has nearly doubled from $7.8 \%$ to $13.8 \%$ yet starting from a lower level. Several explanations can be put forward. First, there is a pronounced lack of all-day childcare and out-of-school-hours care supply, and unsubsidised care is very expensive (the highest in the OECD). As an example, children typically go home at lunch-time since school cafeterias are rare, making it difficult for a parent or a caregiver not to be home at that time. Third, marginal income tax rates for second earners, typically women, are very high, creating disincentives for working long hours. Fourth, a non-negligible net wage gap (about 7\%) triggers specialisation whereby the least paid person in the household spends relatively more time looking after the children. Finally, women often hit a "glass ceiling", making it difficult to mount the corporate ladder to senior positions of responsibility, which are rarely available on a part-time basis.

Figure 2. Labour market participation rates by gender, 2012

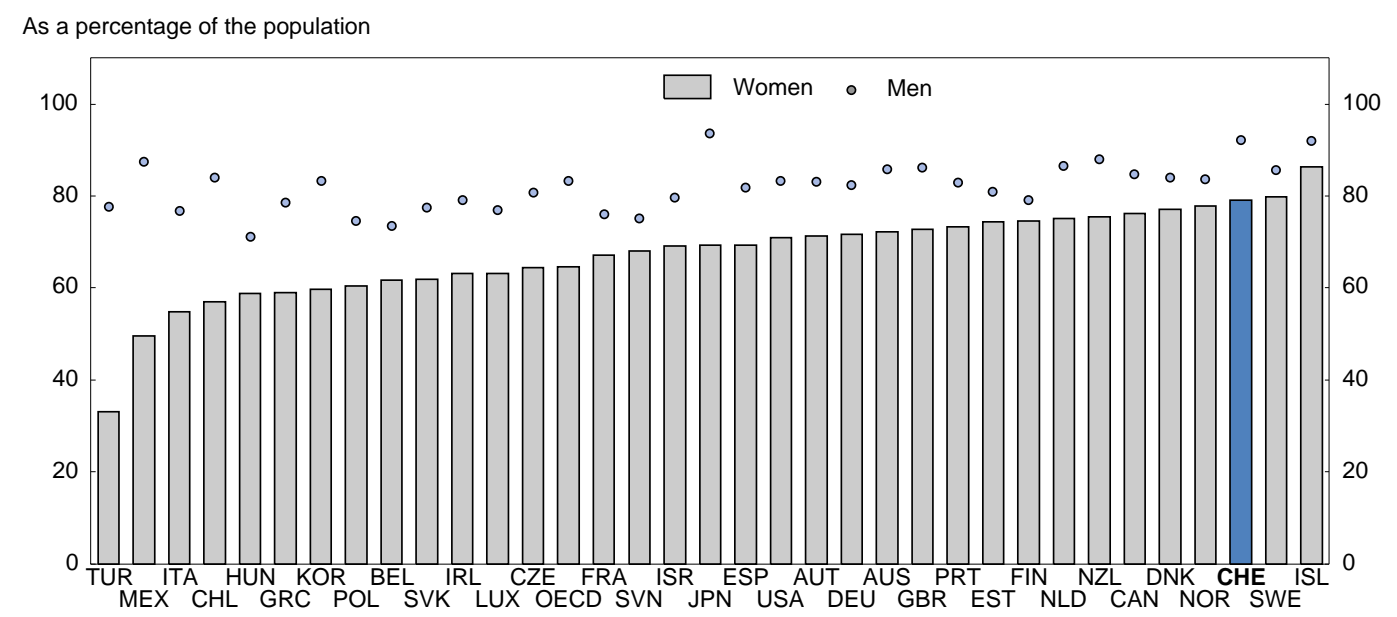

Source: OECD, Labour Force Statistics database 2013. 


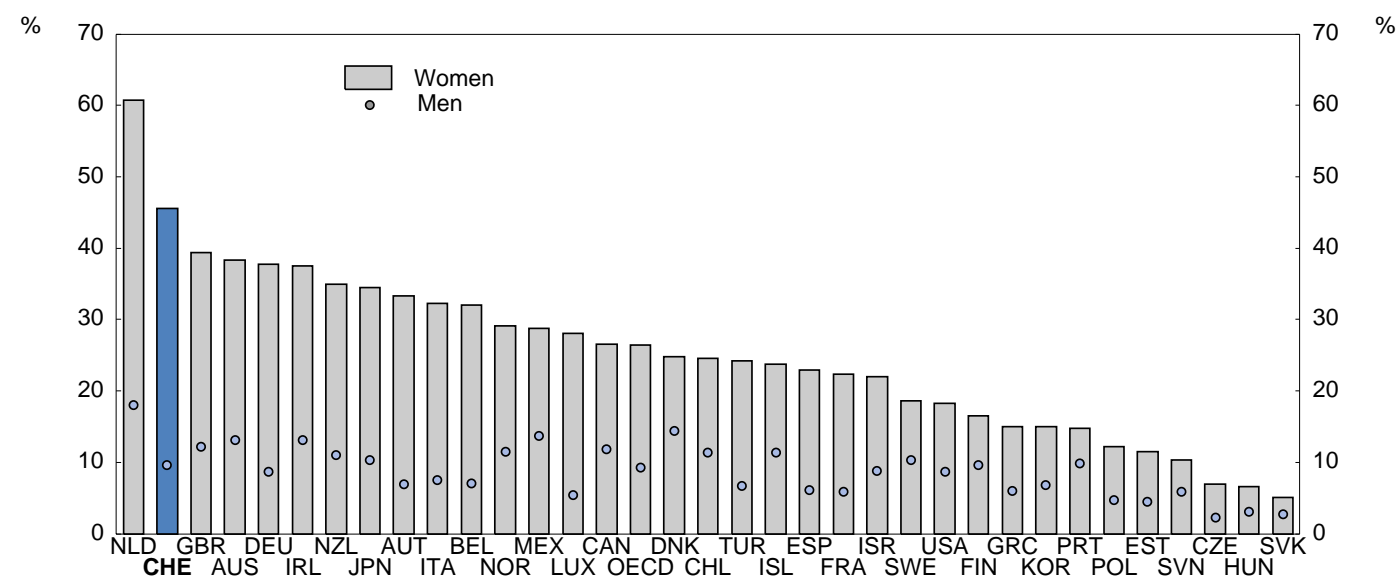

Source: OECD, Labour Force Statistics database 2013.

\section{Wage gap}

In 2010, the gross gender pay gap (measured by the difference between men's and women's median wage divided by men's median wage, not controlled for observable differences) remained above the OECD average at $18.4 \%$ of median earnings for full-time equivalent employment (Figure 4). It increased slightly to $18.9 \%$ in 2012 . It is larger in the private than in the public sector. Trying to explain this gap, calculations conducted by the University of Fribourg using 2010 data from the Swiss Earnings Structure Survey have shown that $62.4 \%$ of the gross pay gap (11.5 percentage points out of the 18.4 ) can be explained by observable differences in education, experience or position. Room for additional progress remains, however, as six OECD countries now have gross median gender pay gaps smaller than $10 \%$. The net wage gap, which controls for observable differences, sits at $6.9 \%(18.4 \%-11.5 \%)$.

Figure 4. Gross gender gap in median earnings of full-time equivalent employees, $2011^{1}$

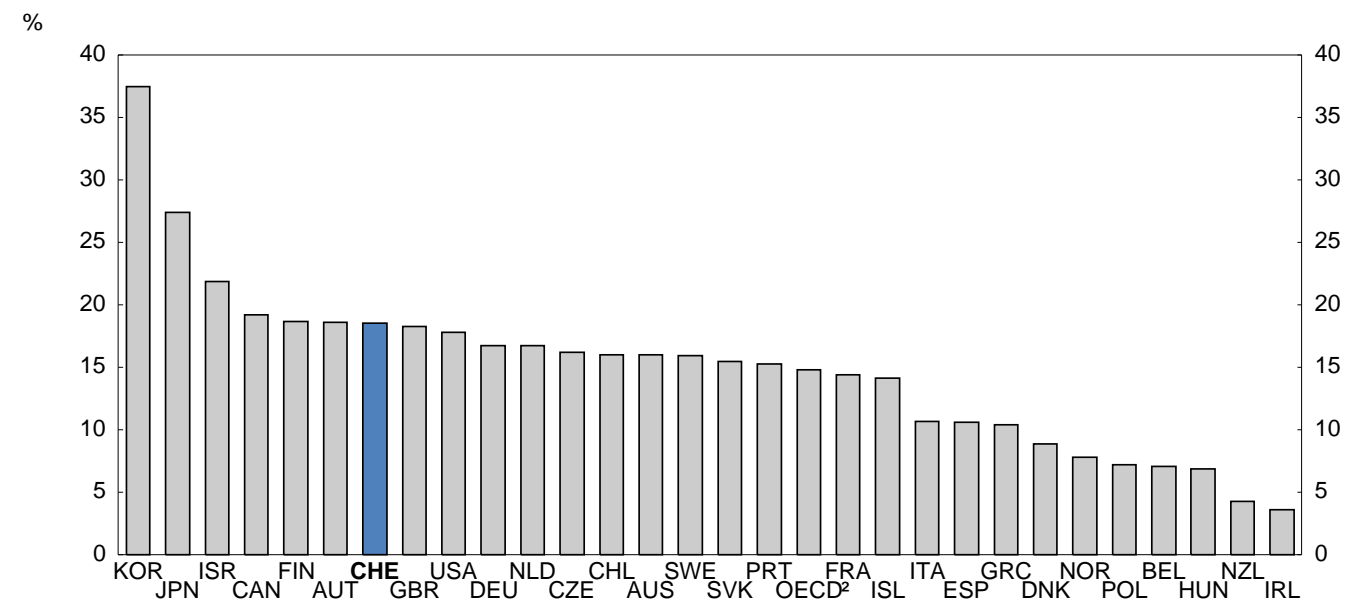

1. The gender wage gap is calculated as the difference between median earnings of men and women relative to median earnings of men; 2010 for the Netherlands.

2. Unweighted average of 29 countries.

Source: OECD, OECD Employment Outlook 2013. 


\section{Leadership positions}

Despite documented progress in education and the labour market, women are still underrepresented as entrepreneurs and in leadership positions. More often than men, women tend to leave their jobs or fail to move up the pay scale, a phenomenon known as the "the leaky pipeline" or the "glass ceiling". As a result, the share of women in managerial or direction positions, at 33\% in Switzerland, does not match their $45 \%$ share of the labour force. In addition, the higher up the pay scale, the greater the differences in career opportunities and compensation. While on average the gross wage gap in OECD countries stands at 15.7\% (18.9\% in Switzerland as noted), for top earners it rises to $20.9 \%$ in OECD countries and $25.4 \%$ in Switzerland (OECD, 2012a). Women also make up a small percentage of company board members, $11.6 \%$ in Switzerland for the largest firms versus a European average of 15.6\% (Egon Zehnder, 2012) and entrepreneurs, defined as persons taking on the risk of setting up a business.

\section{Education: overall equality in attainment, but gender differences in subject studied}

In OECD countries education is generally compulsory up to at least age 15 , and the problem is no longer about girls not enrolling in upper secondary school (as it remains in some parts of the world) but more about boys who are more likely to drop out before completing it. As a result, younger women are increasingly better educated than their male counterparts in OECD countries (OECD, 2012c).

Switzerland is no exception. Significant progress has been made in raising women's educational attainment as can be seen in rising tertiary education enrolment numbers and expected years of schooling. Swiss women also have high aspirations and benefit from about the same amount of financial support as men do, from either parents, municipalities, cantons or the Confederation. This has translated in rising graduation rates for women and a spectacular catch-up, as women are now more numerous at tertiary level than men. On the downside there remains a strong gender-typical distribution of training and specialisations. This section reviews progress and challenges and highlights possible avenues of policy improvement.

\section{Progress in educational attainment}

While just 15 years ago girls' expected duration of schooling was still a full year shorter than boys' (15 years for girls, 16 for boys), today both can expect to attend school for nearly 17 years (Figure 5, Panel A). This achievement is important and may explain part of the reduction in the gender gross wage gap. Empirical evidence collected for the 2012 OECD Gender Initiative (Box 1) confirmed other studies that investment in education has high returns: one extra year of average education (corresponding to a rise in human capital by about $11 \%$ ) leads to an average increase in output per capita of around $9 \%$. 
Figure 5. Progress in educational attainment

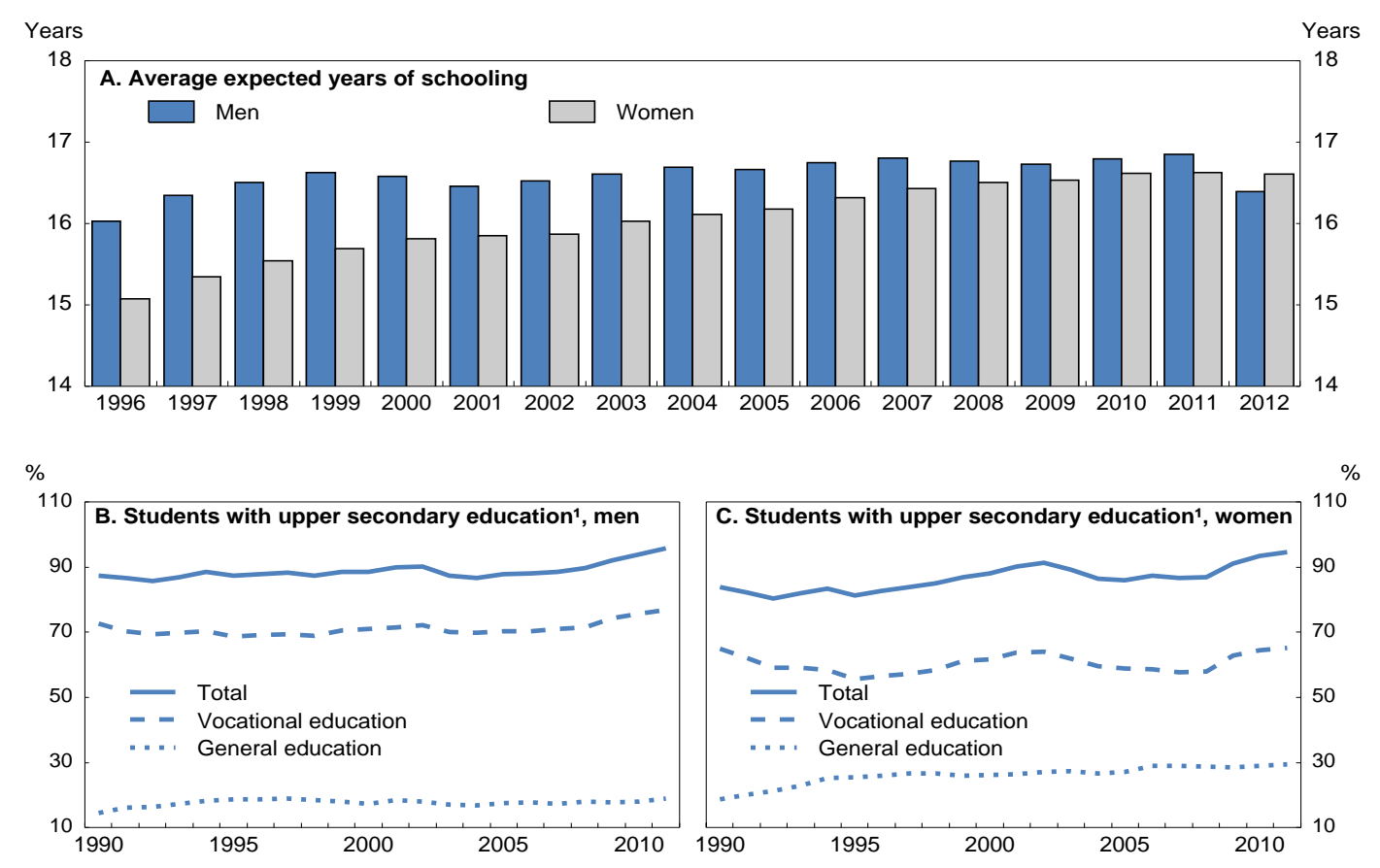

1. As a percentage of the population in the typical age of upper secondary graduation.

Source: FSO.

\section{Box 1. The OECD Gender Initiative}

The OECD has been working on gender equality for more than 30 years. The first OECD Declaration on Gender was issued in 1980. In 2010 the OECD launched its Gender Initiative (OECD, 2012b) to examine existing barriers to gender equality in Education, Employment and Entrepreneurship (the "three Es"), with the aim of improving policies and promoting gender equality in the economy in both OECD and non-OECD countries alike.

The OECD Gender Initiative presented its initial findings in the Gender Report published in May 2011 for the $50^{\text {th }}$ Anniversary Meeting of the OECD Council at Ministerial Level in Paris. In addition, a special report on gender equality in the three Es in OECD countries in the Pacific Rim and other APEC countries was prepared for the APEC Women and the Economy Summit (WES) held in September 2011 in San Francisco.

In 2012, the OECD published a flagship report 'Closing the Gender Gap: Act Now' (OECD, 2012a) and launched the Gender Data Browser (www.oecd.org/gender) with 16 key indicators focusing on gender gaps in OECD countries and the key partner countries. In the course of 2012, the browser was developed into a one-stop gender data portal, which shows the relative standing of countries on the various dimensions of gender equality in the three Es with the aim of monitoring progress over time.

Another sign of the disappearing gender gap in education is the increase in the percentage of women by level of education. Starting with upper secondary education, because of the dual tracking system, students are separated according to abilities or preferences. A first group goes for vocational training, potentially up to universities of applied sciences. A second group goes for general secondary education often leading to traditional academic universities. While girls and boys have the same graduation rate from secondary education (94\%), a higher proportion of boys graduate from vocational secondary education ( $75.7 \%$ in 2010 versus $64.4 \%$ for girls) and a higher proportion of girls' graduate from general secondary graduation (29.1\% versus $18.1 \%$ ) (Figure 5, Panels B and C). 
Looking at the percentage of men among graduates at upper secondary and tertiary level (Table 1), it appears that girls are doing a little better than boys overall, yet it varies greatly by type of diploma. In particular, girls represent the majority of Baccalaureate graduates, while boys represent the majority of vocational education and training (VET) graduates.

Table 1. Graduates, percentage of men, 2011

\begin{tabular}{lc}
\hline & Men in \% \\
\cline { 2 - 2 } Upper secondary level & \\
Baccalaureate (3A) & 43 \\
Vocational baccalaureate (3A) & 53 \\
Specialised baccalaureate (3A) & 14 \\
Vocational education and training (3B) & 55 \\
Tertiary level & \\
PET $^{1}$ colleges (5B) & 54 \\
Federal PET diploma (5B) & 63 \\
Advanced Federal PET diploma (5B) & 76 \\
University Bachelor (5A) & 48 \\
University Master (5A) & 50 \\
University of applied sciences Bachelor (5A) & 45 \\
University of applied sciences Master (5A) & 46 \\
PhD (6) & 57 \\
\hline
\end{tabular}

1. Professional Education and Training.

Source: FSO.

In tertiary education, the percentage of women enrolled in tertiary education, especially HEU (Hautes écoles universitaires) and HES (Hautes écoles spécialisées), has more than doubled since 1980 (Figure 6) and is now on par with men's. In 2005 the Federal Statistics Office (FSO) noted that among the 60-69 year age group, the percentage of people holding a university degree was four times higher among men than women. But in the 20-29 age group there were as many women with university degrees as men. This trend has not stopped since then, and by 2011 the difference in entry and graduation rates was 5 percentage points in favour of women (Figure 7).

Figure 6. Percentage of female students, by level of education, 1996-2010

As a percentage of total students by level of education

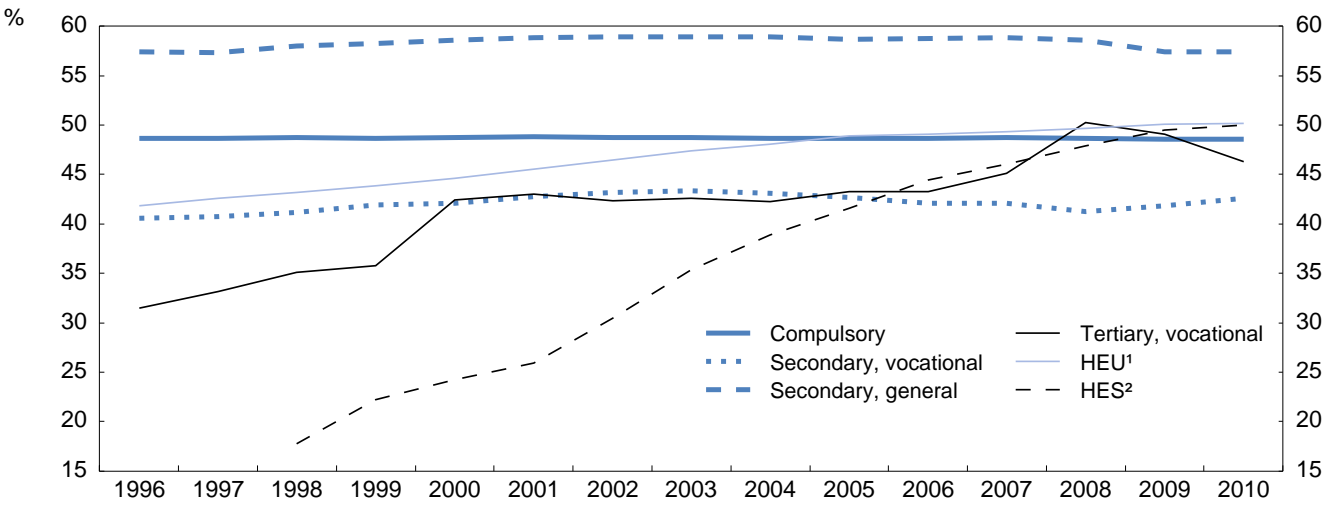

1. General universities (Hautes écoles universitaires).

2. Universities of applied sciences (Hautes écoles spécialisées).

Source: FSO. 
Figure 7. Entry and graduation rates in non-vocational tertiary education by gender
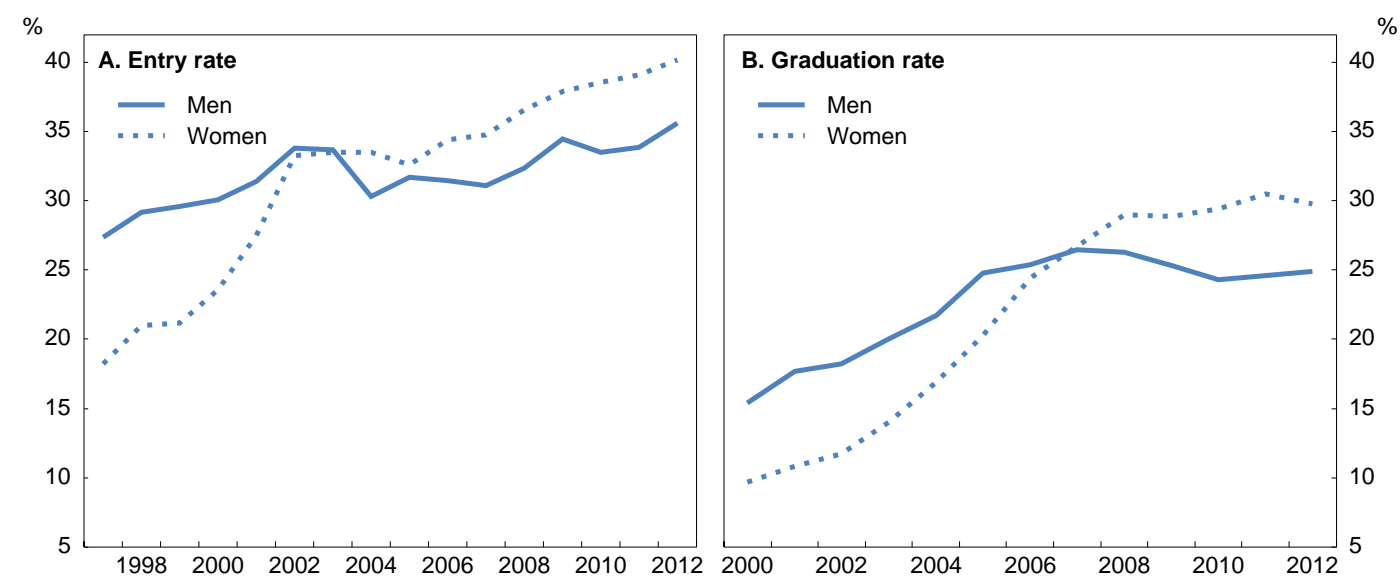

Source: FSO.

The picture for Switzerland relative to other OECD countries is less impressive, however. Perhaps due to the importance of vocational training, tertiary education enrolment rates for both men and women are noticeably lower than elsewhere (Figure 8). However, similar to Switzerland, enrolment and graduation rates in the OECD are now higher on average for girls than for boys. In some countries enrolment/graduation rates among young women exceed those of young men by 25 percentage points or more.

Figure 8. Tertiary education enrolment rates, $2011^{1}$

Sum of enrolment rates at each age level ${ }^{2}$, in per cent

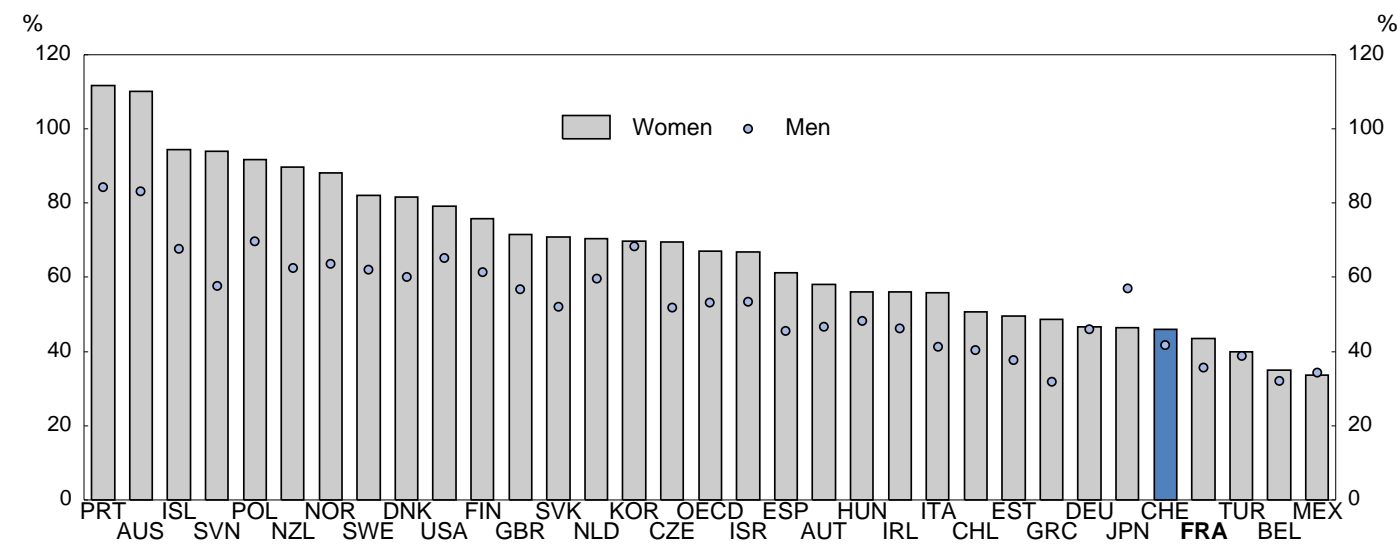

1. Tertiary type-A education.

2. Enrolment rates represent the estimated percentage of an age cohort that is expected to enter a tertiary programme over a lifetime. Entry rates can be above $100 \%$ when large numbers of foreign students enrol at university, for instance.

Source: OECD, Education at a Glance 2013 database.

While Switzerland is a relatively small country (with 8 million people), it is well known for its strong regional differences in culture and language, in part due to the defining role played by cantons both in terms of identity, and social and economic policy. This diversity is also reflected in the share of women in tertiary education graduates. In 2011 , while the average was $45 \%$, it ranged from a low of $35 \%$ in Central 
Switzerland to a high of $55 \%$ in the North West. Similar regional differences in the wage gap are highlighted below.

\section{Progress supported by high expectations and a fair level of financial support}

The progress realised in lifting girls' enrolment and graduation rates has been supported by high expectations among girls themselves and by financial support. Looking at the percentage of 15 year-old students who expect one of the ten most popular jobs, Swiss and OECD female students score higher than males. On the financial side, men and women receive roughly the same amount of public financial support for tertiary education. On the one hand, women received a greater number of grants at the federal and cantonal levels (with a few exceptions: Zug, Uri and Obwalden), which may reflect their overall higher enrolment rates and lower drop-out rate. On the other hand, also reflecting the greater number of female recipients, annual grant amounts tend to be marginally higher for men on average: CHF 6409 versus CHF 6293 for women. A slightly larger difference applies to the total amount of resources available (coming from work, parents or grants): male students enjoy an average CHF 1850 per month versus CHF 1800 for females. Regarding the type of resources, there is no significant difference between men and women: labour income represents $33 \%$ and parental help $55 \%$ of total resources. The rest (12\%) is split between grants and others (source: FSO, Social and Economic Conditions of Student Life).

\section{Solid academic performances for girls at school}

Girls outperformed boys in the 2012 PISA reading assessment by 36 points, a difference close to the average OECD country ( +37 points), while boys performed better in mathematics by 13 points (compared to an OECD average of +10 points) and natural sciences by 6 points (compared to an OECD average of +2 points, Figure 9). Interestingly, in the PISA 2012 assessment, those gaps between boys and girls in Switzerland are all smaller than the gaps in the PISA 2009 assessment.

Figure 9. PISA scores

2012

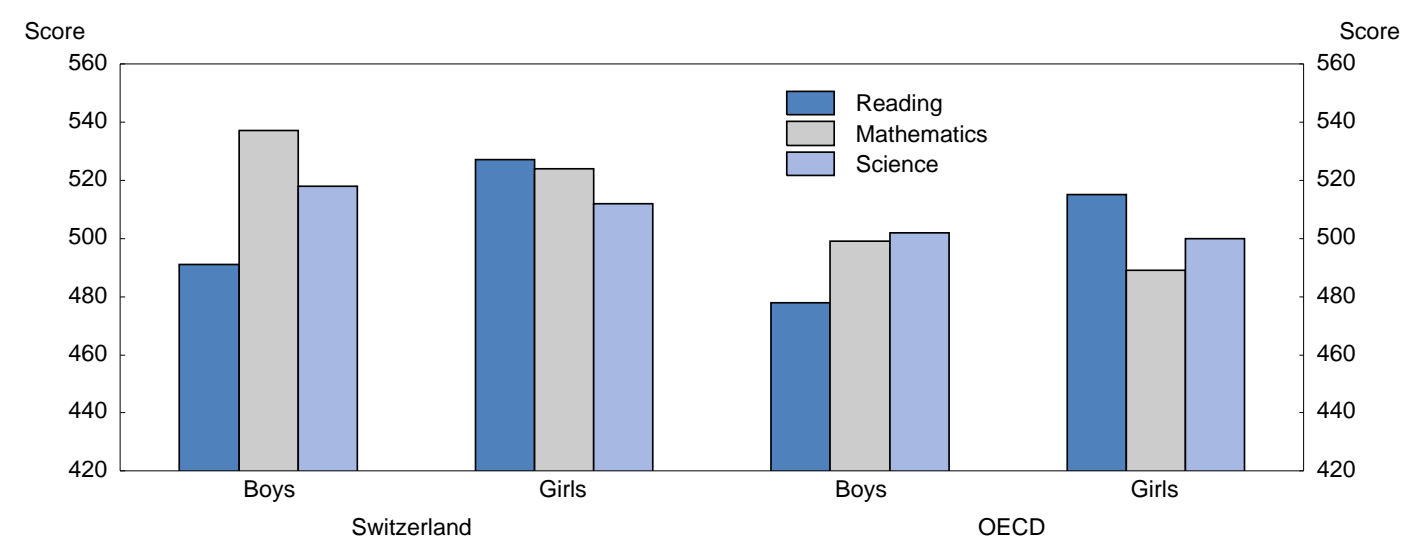

Source: OECD, Results of PISA 2012 database.

Another gauge of girls' achievements in the Swiss education system can be found in the number of diplomas (matura) - whether Gymnasium i.e. academic, Professional or Specialised; see Box 2 below delivered to students finishing upper secondary education. A total of 33656 matura were conferred in $2011,56 \%$ more than in 2000 . This represents $35 \%$ of the age cohort, compared to only $25 \%$ in $2000.54 \%$ of them were delivered to women. Looking at the type of matura, $56 \%$ of them are gymnasium matura, $38 \%$ professional and $4 \%$ specialised. Women receive a majority of gymnasium and specialised matura, 
$57 \%$ and $86 \%$ respectively, but only $47 \%$ of professional matura (Figure 10 ). Based on current enrolment rates, the total number of gymnasium matura conferred has peaked and should fall by around 5\% by 2020 (FSO, 2013a).

\section{Box 2. The matura in the Swiss education system}

Matura validate upper secondary education. They attest that their holders have the required knowledge and aptitudes to pursue university-level studies. In Switzerland there exist three types of matura: the gymnasium matura validates upper secondary general education and allows entry into the 12 traditional academic universities and also the 10 universities of applied sciences after having completed one year of practical experience; the professional matura validates upper secondary professional education received on top of apprenticeships and opens the door to universities of applied sciences or also (after having passed an additional examination) to the academic universities; and the specialised matura grants access to the universities of applied sciences in a few bachelor's programmes related to their orientation and/or under certain conditions.

Figure 10. Evolution of the percentage of women in matura, by type

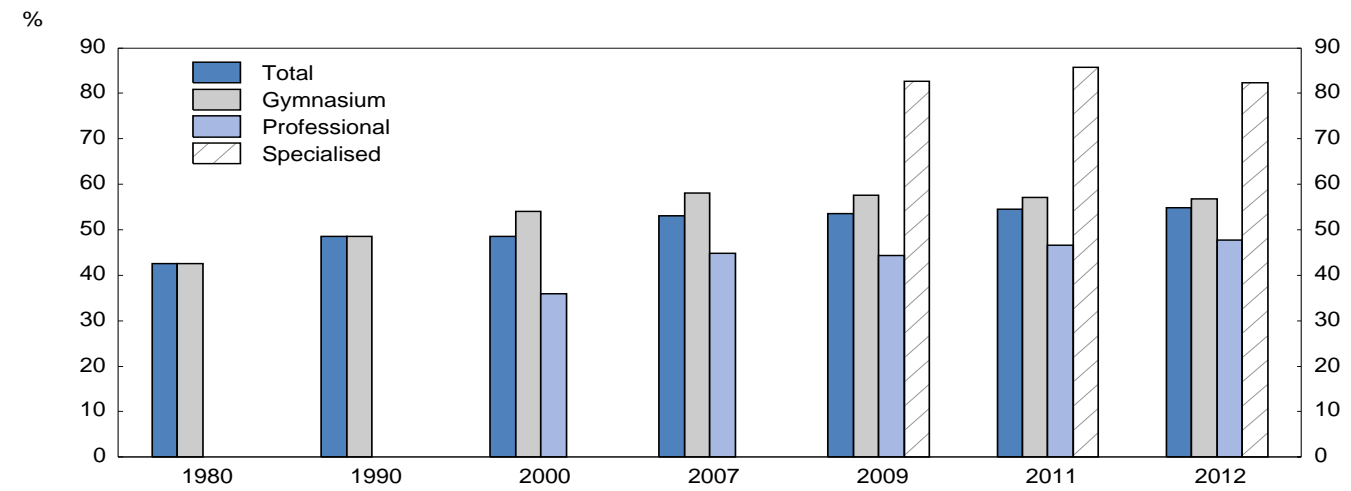

Source: FSO.

\section{Yet education choices differ sharply by gender}

While progress in enrolment and graduation rates in higher education for women has been strong in Switzerland over the last 25 years, choices of study remain heavily influenced by gender. Looking at the degrees awarded in universities of applied sciences by gender, men represent the vast majority in traditional male subjects, such as engineering and IT, architecture and construction, whereas women are massively over-represented in social work, teacher education, psychology, languages and health (Figure 11). Switzerland is also one of the countries with the lowest percentage of females expecting a career in engineering and computing professions. Making the study of hard sciences, social sciences and health equally inclusive and attractive for boys and girls has been identified as an education priority by the OECD, not only in Switzerland (OECD, 2013).

Some researchers have suggested that a possible explanation for this gender-segmented allocation of students across fields of study may be found in the dual-track system. The Swiss post-compulsory education system can be split between VET, capturing two thirds of students, and gymnasiums providing general academic education for the remaining third. The split generally happens at age 15-16, requiring students to make career choices early on. Statistical analysis (Imdorf et al., 2013) has shown that cantons with proportionally more gymnasiums have a lower degree of gender-typical allocation of men and women across fields of study. There can be several reasons for that. First, more academically oriented education 
systems offer more opportunities for students to change career paths according to preferences and abilities. By contrast the variety of differentiated education options in the VET system may favour gender-typical choices at an age when gender plays an important role in shaping individual identity. Second, the academic track allows students to be more mature before making career choices. Recent research has shown that differences in the way people think or behave are rooted in individual differences in brain anatomy and connectivity, which develop later in life (Mueller et al., 2013). This maturity allows them to be less influenced by their friends and family, who may suggest gender-typical careers, and more by their personal interests or comparative advantages. Allowing mentors and positive atypical role models in the family, the educational system and professional life to meet students at an early stage of their career can help boys and girls choose gender-atypical careers, inducing others to follow suit. Role models can also raise awareness of the consequences of educational choices for career and earnings prospects. Note also that students from lower socio-economic backgrounds have been shown to be more influenced by gender stereotypes.

Figure 11. Degrees awarded in universities of applied sciences by gender

As a percentage of total degrees by field of study, $2012^{1}$

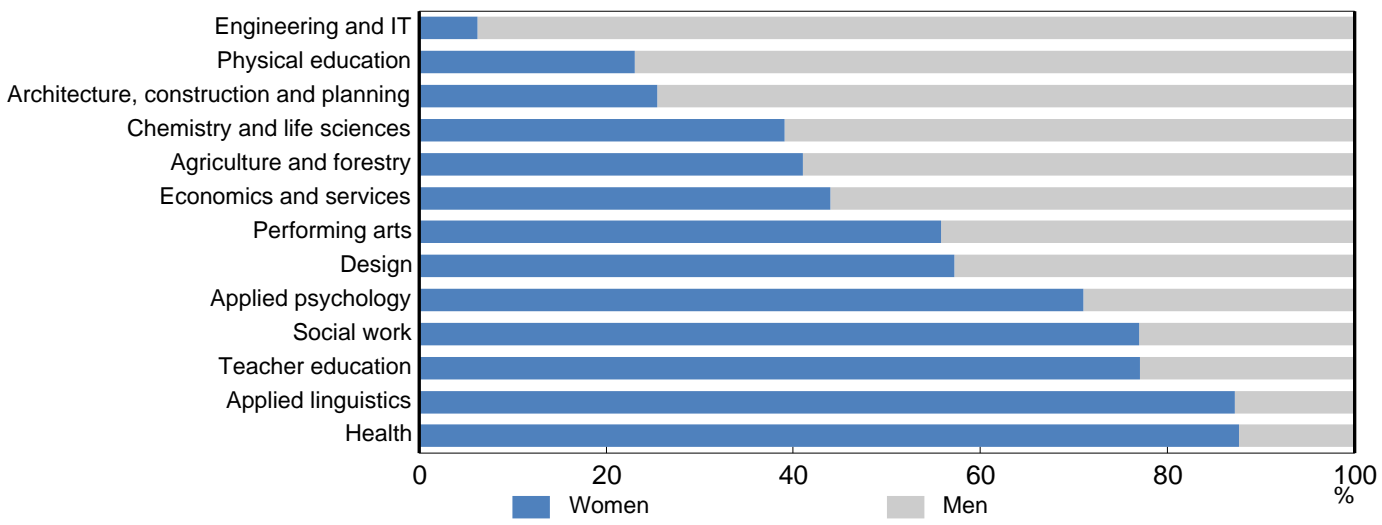

1. Degrees awarded in universities of applied sciences include so-called Diplom, bachelor's and master's degrees.

Source: FSO.

Perhaps a good example of prevalence of gender-oriented choices of careers in Switzerland is the over-representation of women in primary teaching. Though lower than the OECD average of two-thirds, women in Switzerland still account for 59\% of all teachers (Figure 12). Comparing 2012 to 2000, the share of female teachers has risen in all three sectors: compulsory, secondary and tertiary (Table 2).

That girls are not rushing into scientific careers may simply reflect individual preferences. But the choice of a career may also be influenced by family and society values that may conflict with preferences, abilities or personal interests. Evidence collected for the 2012 OECD Gender Initiative, however, seems to suggest that study choices are primarily influenced by academic performance, especially mathematics scores, although that relationship is not strong for boys (see Box 3). 
Figure 12. Percentage of females among teachers, by level of education

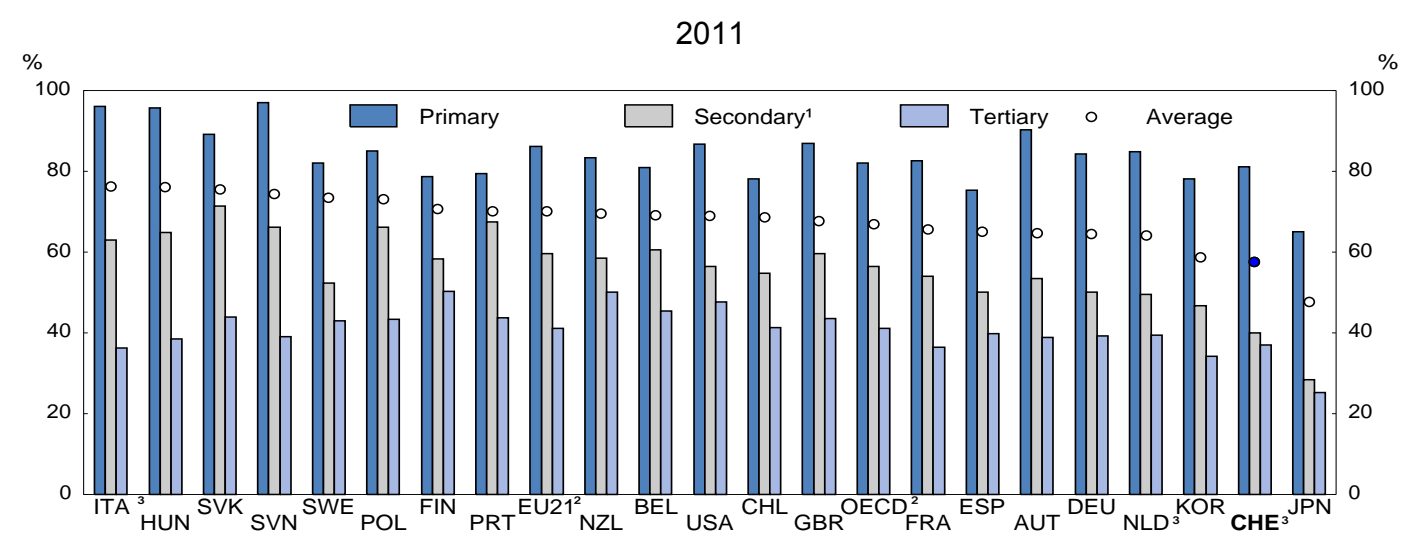

1. Data refer to upper secondary education only.

2. Unweighted averages.

3. Public institutions only, excluding tertiary education for Italy.

Source: OECD, Education at a Glance 2013.

Table 2. Percentage of female teachers, by level

\begin{tabular}{lccc}
\hline & Compulsory & Secondary & Tertiary \\
\cline { 2 - 4 } 2000 & $62.0 \%$ & $31.9 \%$ & $34.9 \%$ \\
2012 & $72.4 \%$ & $41.1 \%$ & $43.4 \%$ \\
\hline
\end{tabular}

Source: FSO.

\section{Box 3. What determines gender differences in subject choice? A selected survey}

Understanding the factors that shape gender differences in subject choice is important to explaining the educational choices of young men and women. New research undertaken with PISA longitudinal studies in a number of countries allows a better understanding of the determinants of gender differences in fields of study in post-secondary education.

Girls are more likely to enter tertiary education than boys. Students' individual attributes play a role in determining whether they enter sciences or arts subjects. Typically, high grades in the last year of secondary school or high mathematics scores influence girls' choices of science-related subjects. This relationship, on the other hand is not strong for boys. Young women are more likely to aspire to professional careers (OECD, 2009) and thus at university entry are more likely to choose courses in which they have a comparative advantage. In Australia, for example, young men associate science courses less with university entry and more with VET career pathways in science such as apprenticeships. Since access to VET courses is not generally based on academic merit, performance in mathematics at age 15 has no significant effect on their choice of science courses. Evidence for the Czech Republic shows a similar pattern: girls with high grades at secondary level choose to enter university, while boys are more likely to pursue vocational education in a technical or science-related field (OECD, 2012c). In Switzerland, students also tend to choose post-secondary science courses based on their mathematics scores (Bergman et al., 2012).

Family background is an additional factor, one of the most powerful and consistent predictors of educational attainment: boys appear more affected than girls by socialisation within the family. Peer pressure has also been documented to play a role, but there is little evidence that student-teacher gender matching improves students' performance (Salvi Del Pero and Bytchkova, 2013). 
To its credit, the Swiss education system has made some notable progress towards increasing the diversity of career opportunities for boys and girls, such as the adoption of the professional matura, which opens the door to universities of applied sciences. More progress can be made by favouring a better, less gender-typical allocation of human capital. Fostering greater mobility between career paths by creating well-marked and more numerous pathways can also help reduce gender's role in study choices. Life-long opportunities for skills development allowing people to make career changes later in their lives should also be considered.

\section{Box 4. Recommendations to make the education system more gender balanced}

- Use role models to make hard sciences more attractive for girls and social sciences and health more tempting to boys, and raise awareness of career and earnings prospects associated with study choices.

- Inform students about rewarding gender-atypical career choices.

- $\quad$ Facilitate greater mobility between career paths by creating well-marked and more numerous pathways.

- $\quad$ Support life-long opportunities for skills development allowing people to make career changes later in their lives.

- $\quad$ Reduce the influence of socio-economic background on the extent of gender-typical study and career choices by providing earlier and more intensive guidance for disadvantaged students, and greater financial support.

\section{Reconciling work and family life}

The Swiss labour market retains several traits that make it difficult for women to take full advantage of their education, in terms of opportunities, careers, work-life balance and wage equality. This section reviews the role and specificities of women in the Swiss labour market, the transition from education to work and how it can be improved. Special attention is devoted to helping working men and women reconcile their family life with their professional aspirations.

\section{A strong presence on the labour market not in proportion with the volume of hours worked}

Triggered by gains in female educational attainment, the high female participation rate is the consequence of a slow increase that started in the late 1960s. The participation rate of women in their early thirties was $35 \%$ in 1970 . Over the following 30 years this percentage doubled to $70 \%$. Projections based on the current trend in census data show that the female participation rate should be very similar to the male rate by 2060 with the exception of women's peak child-bearing and -rearing years (30 to 45). The equalisation is also projected to affect immigrant women (Figure 13). This high participation rate, combined with an above-average female employment rate, makes Switzerland very similar in that dimension to the Nordic countries, which have been leading the OECD in terms of women's labour market integration (Figure 14, Panel A). As a result, the Swiss labour force has been moving towards a more equal gender mix, from 34\% female in 1960 to $45 \%$ in 2012 (Panel B).

In terms of flows, a higher percentage of women enters and exits the market; in 2011 the female (male) entry and exit rates (as shares of the labour force) were 6.8\% (5.0\%) and 7.7\% (4.6\%). Such differences may be explained at least in part by women moving in and out of the labour force around child-bearing times. However, it is worth noting that the trend in turnover is flat for men, whereas it has been falling for women, with both entry and exit rates near or above $10 \%$ in the early 1990 s. Hence, this gender gap has shrunk over time. 
Figure 13. Labour market participation rates by age ${ }^{1}$

As a percentage of the population
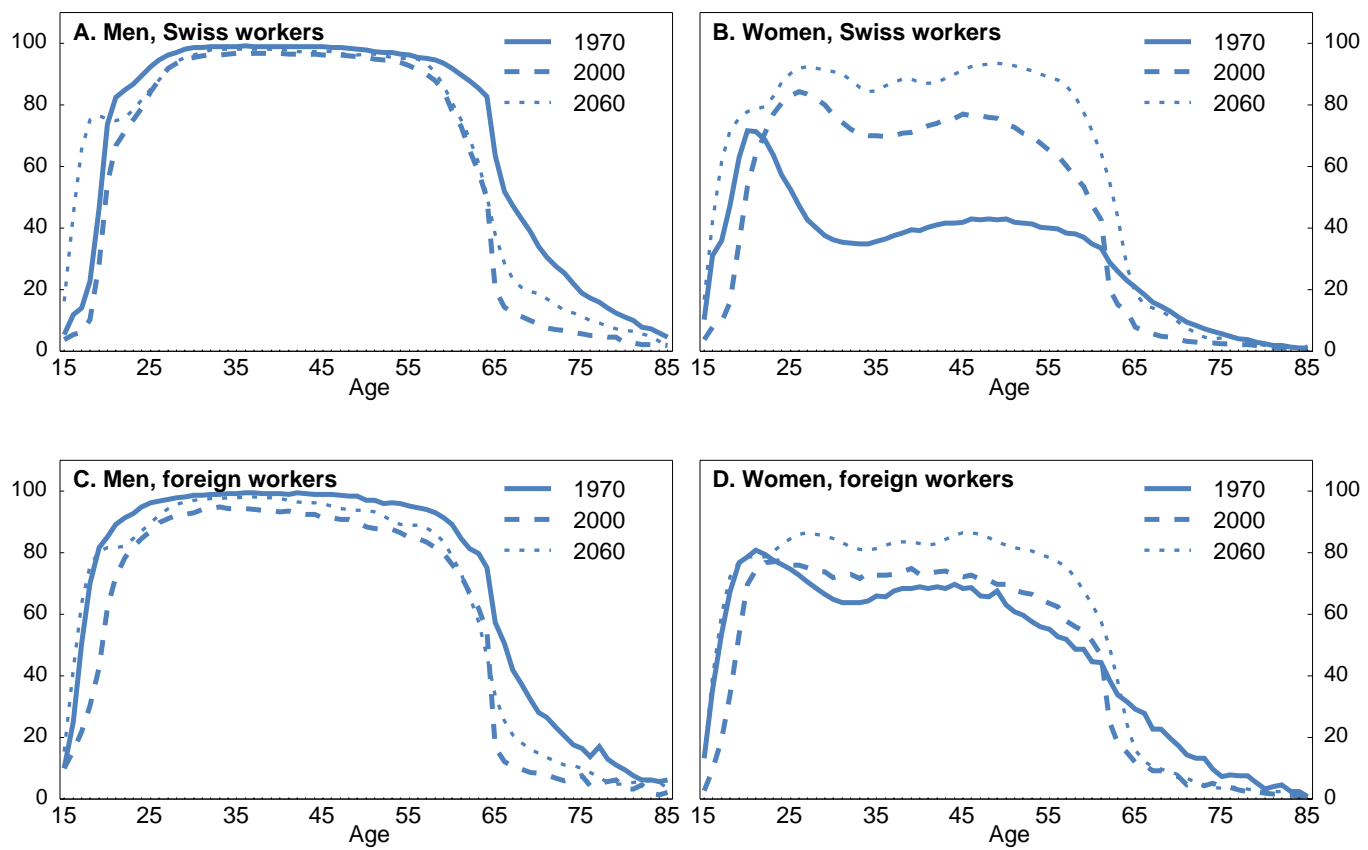

1. In contrast to participation rates based on the SLFS, employed pertain here to individuals working at least 6 hours per week while apprentices are counted as non-active as others in full-time education.

Source: Census data compiled by Professor George Sheldon from the University of Basel.

Figure 14. Female employment rate for those aged 15 to 64 and workforce composition
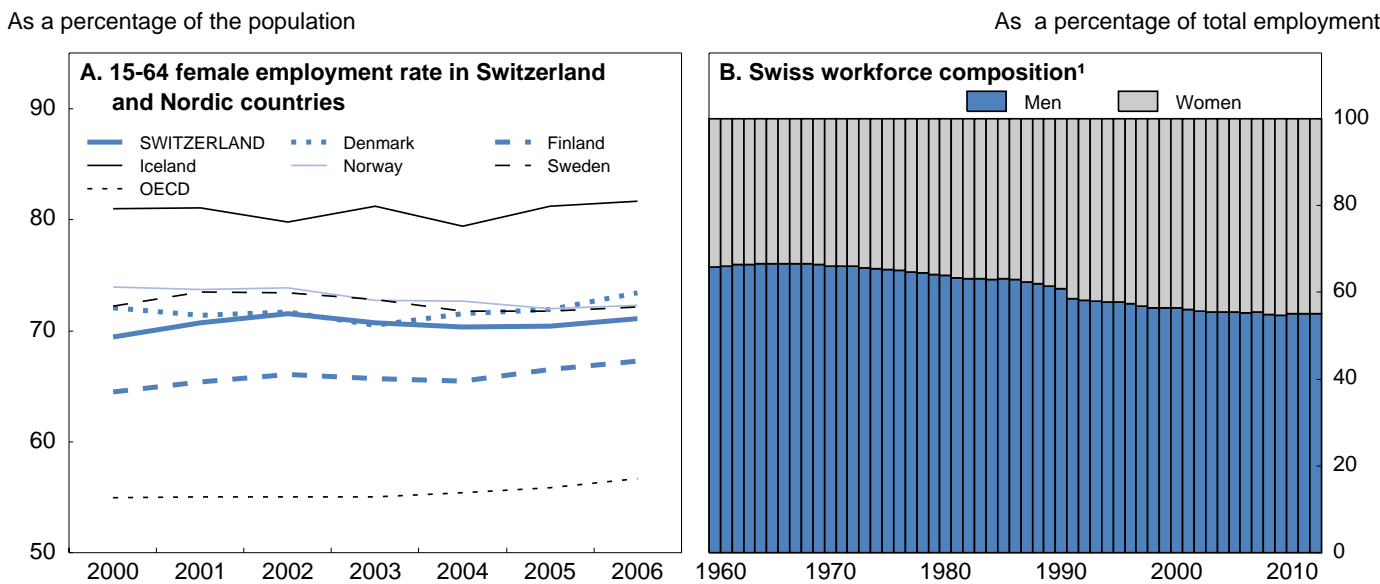

1. As of 1991 the workforce comprises every employed person working at least one hour per week instead of six.

Source: OECD, Labour Force Statistics 2013 database Panel A); FSO, Swiss Labour Force Statistics (Panel B). 


\section{Labour market outcomes reflect education choices and constraints}

The transition from education to paid work is a critical moment that can have lasting consequences on both work opportunities and earning capacities. It is primarily affected by the prior student choices. Echoing Figure 11 in the section on education, the distribution of female workers among professions seems to reflect their choices of study (Figure 15). It also appears that Swiss women are broadly similar to those elsewhere in the OECD in their job structure, at least in the services sector. The proportion of Swiss women in education, health, social and community work is high, but close to average OECD levels. Conversely, the percentage of women working in the public sector, a traditional preferred choice for women, is near $50 \%$, below the OECD average, and noticeably below some Northern European comparator countries.

Despite earlier documented progress in tertiary attainment, women remain under-represented in science and technology occupations. According to the FSO, in 2008 only $31.6 \%$ of all researchers in Switzerland were women. This average comprises a low $20.6 \%$ in the private sector and a high $41.0 \%$ in tertiary education institutions (Figure 16). As an example, the proportion of women in Swiss academia decreases the further up the hierarchy one goes: only $42 \%$ of $\mathrm{PhD}$ graduates are women, one of the lowest rates in Europe (European average: 46\%). This percentage decreases further in the higher rungs of the academic ladder. In 2010 women represented $26 \%$ of faculty with research activity in Swiss universities, still above the European average of $20 \%$. In addition, the proportion of women varies greatly by economic sector and field of study. In Switzerland 63\% of $\mathrm{PhD}$ students who graduated in 2010 in the field of educational sciences were women but only $35 \%$ in mathematics and computer science and $23 \%$ in technical sciences. However, between 2004 and 2008, the average annual growth rate of female researchers $(4.6 \%)$ was higher than that of male researchers $(0.3 \%)$, pointing to a steady equalisation. Women are also underrepresented among inventors and patent applicants, although this too is changing. In 1980 women were only $2 \%$ of the applicants for Swiss patents, but by 2011 their share had reached almost 10\% (OECD Gender Portal).

Figure 15. Sectoral shares of female employment
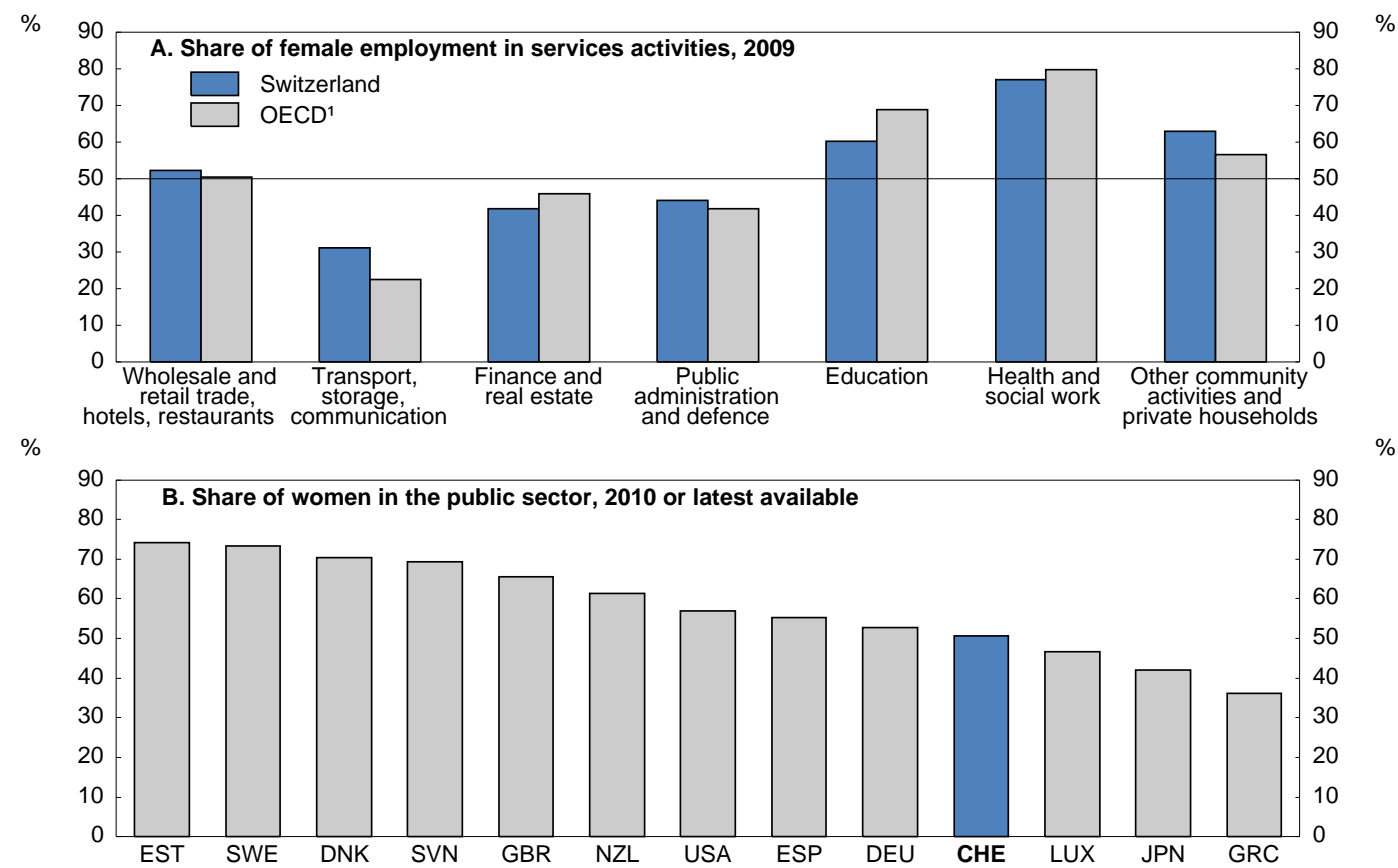

1. Computed across 17 OECD countries for which employment data according to ISIC rev3 classification are available.

Source: OECD (2012b), Gender Equality in Education, Employment and Entrepreneurship and OECD Employment database; ILO. 
Figure 16. Employment in R\&D activities in Switzerland, by sector and gender 2008

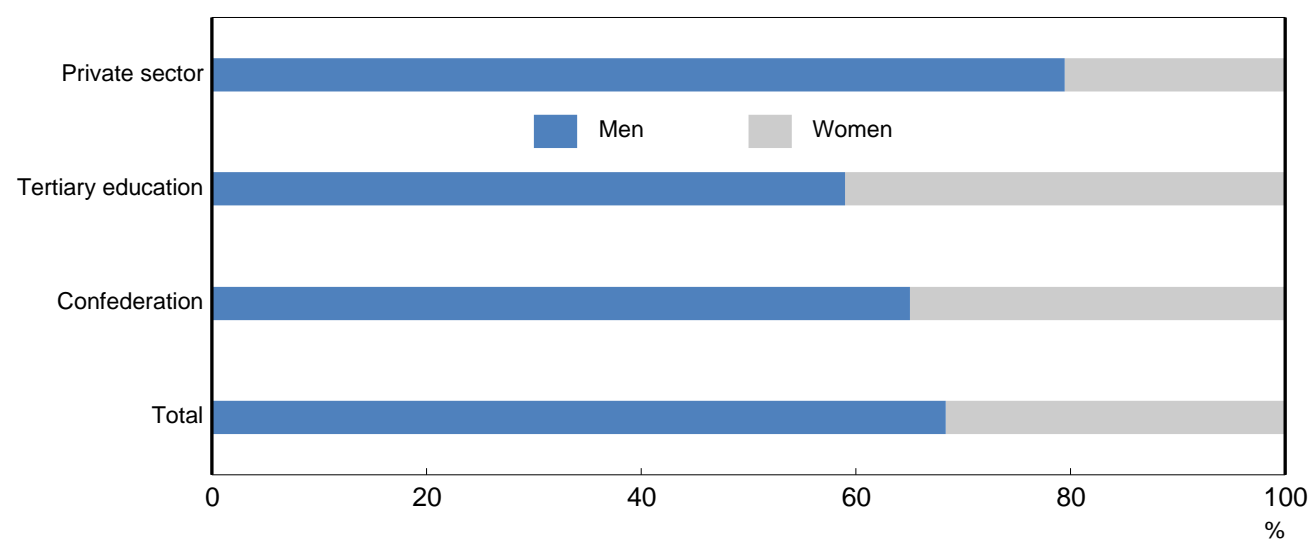

Source: FSO.

The average expected wage premium enjoyed by those with tertiary education relative to secondary in Switzerland was $55 \%$ for women versus $44 \%$ for men in 2011 . The 11 percentage point difference is much bigger than that of the average OECD country, where the premia were $68 \%$ versus $67 \%$ that year, respectively. The tertiary education premium rose less for men (by 10 percentage points) than for women (13) between 1999 and 2011 in Switzerland. A similar trend was observed in OECD countries with much faster gains made by well educated women $(+21)$ relative to men $(+11)$ during that time (Figure 17). Given the higher premium for women, it is perhaps no surprise that the impact of educational attainment on employment rates is higher for women than for men. Passing from secondary to tertiary raises the employment rate from an average $76 \%$ to $81 \%$ for women, but only from $90 \%$ to $93 \%$ for men (Figure 18).

Figure 17. Relative earnings for those aged 25-64 with tertiary education

Salary for age group 25-64 with secondary education $=0$

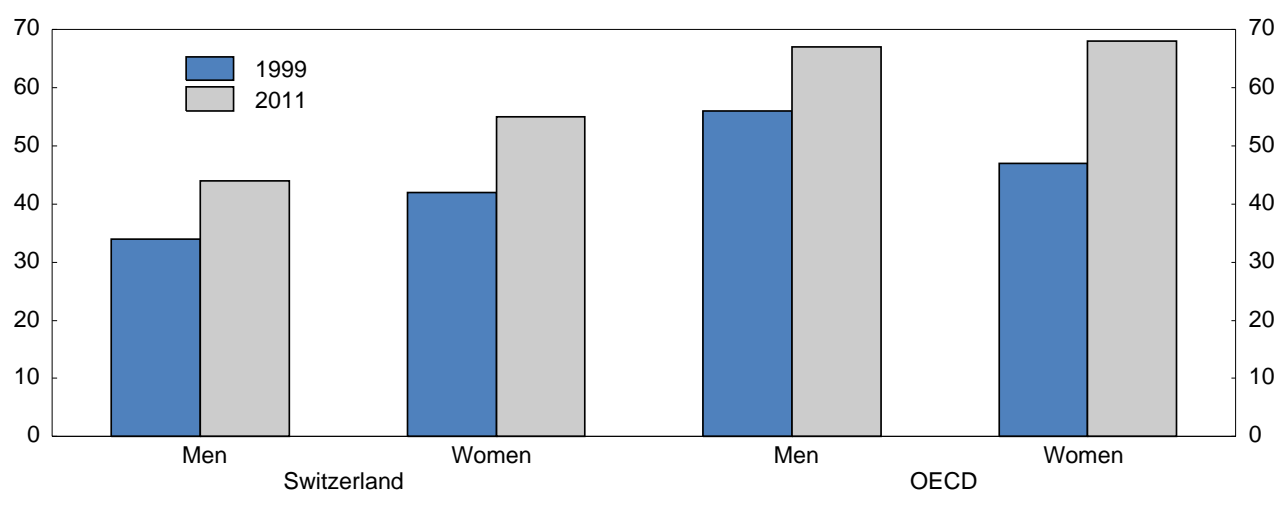

Source: OECD, Education at a Glance 2013. 
Figure 18. Percentage working, by education and gender ${ }^{1}$

Percentage of resident population aged between 25 and 64

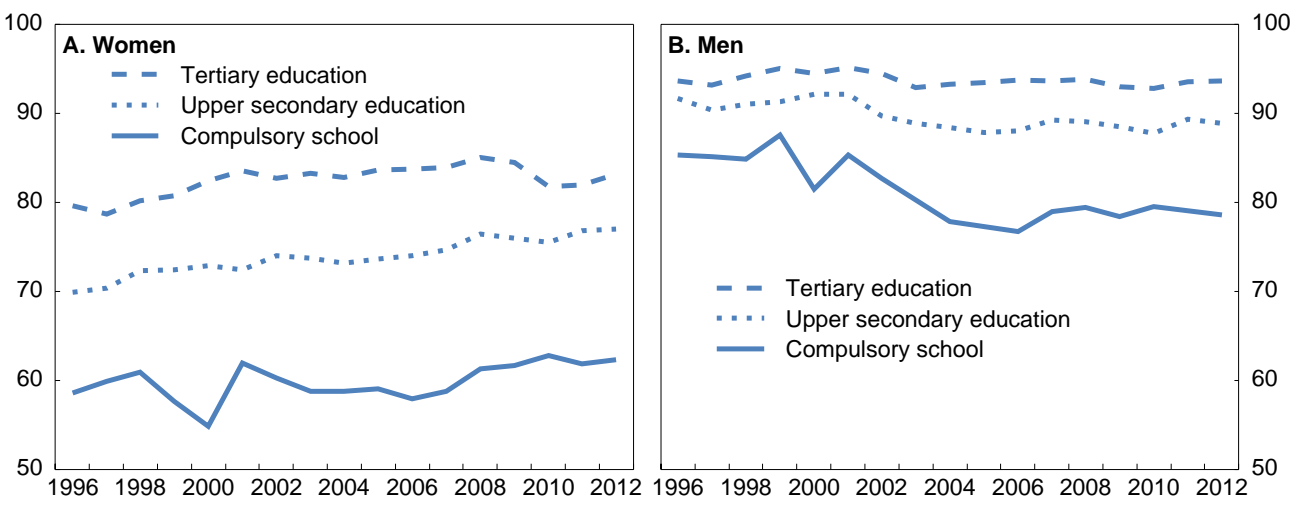

1. Series break in 2002 and 2010.

Source: FSO, Swiss Labour Force Survey.

\section{The lack of a family-friendly working environment forces women to make difficult choices}

Swiss women started to increase their labour market participation in the 1970s. This corresponded to the beginning of a sharp trend rise in the average age of maternity, now above 31 on average, up from 27.5 in the early 1970s, and a steep fall in the fertility rate from above 2.5 children per woman in the mid-1960s to1.5 today (Figure 19). Switzerland's fertility rate is below the OECD average (1.74) and well below replacement levels. To make household work decisions easier and based on comparative advantages rather than constraints or social stereotypes, families with children need a family-friendly environment both at the workplace and at home. This means childcare facilities need to be sufficient in number and affordable in price. Switzerland lacks both. It also requires that family members consider both paid and unpaid working time when sharing household work. Box 5 summarises attitudes towards childcare and work in various countries.

Figure 19. Tensions between work and family life are central to child-bearing decisions
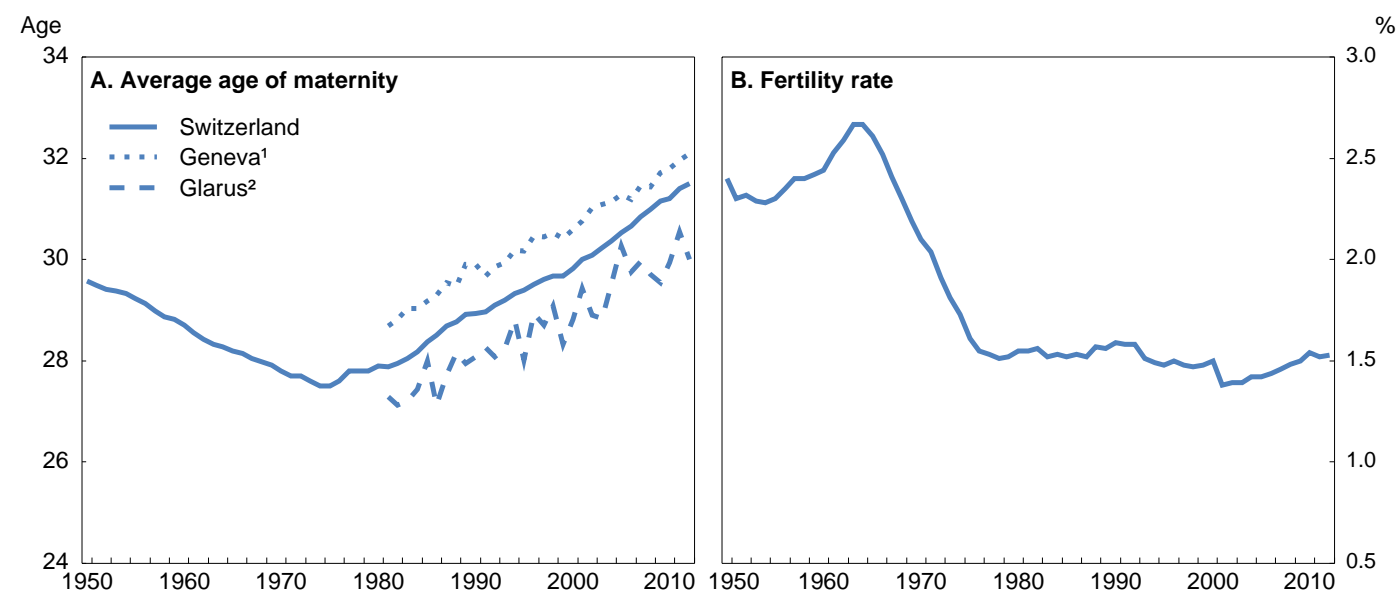

1. Highest.

2. Lowest.

Source: FSO. 


\section{Box 5. Attitudes toward childcare and work}

Attitudes and behaviour towards work and childcare are important drivers of policymaking (Kamerman and Moss, 2009; Lewis, 2009), and existing policies can contribute to changing views and behaviour. Parental attitudes towards mothers' employment vary significantly among countries (Figure 20). In the Nordic countries, where female employment is the norm and where work-family policies have been operating for over 40 years, views towards work and childcare are more gender equal, even though there may have been a small trend reversal among Swedish mothers. By contrast, in Switzerland, Germany, Hungary, Israel, Poland, Portugal, and the Russian Federation, more than half of all parents report a more traditional view of women's labour force participation and childcare commitments. A lack of formal childcare capacity for very young children - which can reinforce parents' attitudes towards employment and childcare (Fagnani, 2002) - may partially explain these responses.

Figure 20. Attitudes of parents towards childcare and work differ across countries, 2010

Share of parents with children under 15 agreeing or strongly agreeing with the statement: "Women should be prepared to cut down on paid work for the sake of the family"
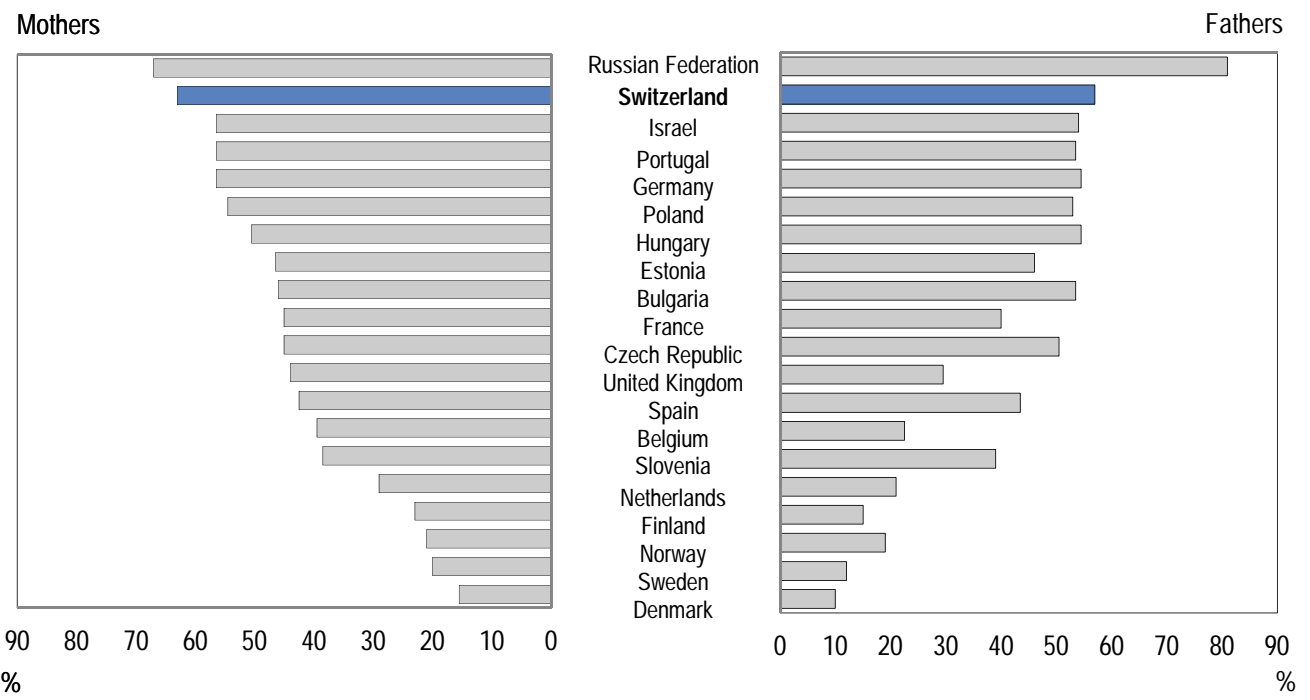

Source: OECD (2012b) Gender Initiative, calculations based on data from the European Social Survey 2010.

The lack of childcare facilities and its price is one of the main impediments to women taking full advantage of their education. While decentralisation has worked well for Switzerland, childcare may be one area where increased federal involvement could help. There is no statutory scheme or legislation governing childcare assistance for the whole country. Childcare policy is managed at the municipal and cantonal levels, resulting in substantial heterogeneity. Also, families living in small towns and communities in the rural parts of Switzerland face greater difficulties than those living in larger cities. The decentralisation of responsibilities can make it difficult for cantons and municipalities to co-ordinate their efforts. The Federal Parliament proposed an amendment to the Swiss Constitution on family policy which would have required the federal government to work with its cantonal counterparts to promote work-life balance through increased support to childcare provision. The amendment included a provision that would have given the Confederation the power to step in and fund some of the measures if the cantons were not doing enough. In a public referendum held in March 2013 the proposed amendment was supported by 54\% of those voting but failed due to a majority of cantons voting against it. The rules of a Swiss mandatory referendum state that for an amendment to the Federal Constitution to be accepted a majority of those who vote and a majority of the cantons must approve it. 
Within the OECD, Switzerland is among the countries with the lowest public childcare and pre-primary education spending as a share of GDP, at just $0.2 \%$ in 2009 , about a third of the OECD average (Figure 21). However, data reported here do not include all local government spending and therefore underestimate public spending on childcare in federal countries like Switzerland. According to a government study (SECO, 2007), in 2005 almost 30\% of mothers of children aged less than 15 (about 21000 women) said that they had to reduce their working hours because of the lack of childcare facilities. Among these women, $41.2 \%$ did not work at all; most of them would have preferred to work part time (2-3 days a week). Only a minority would have liked to work full time.

Figure 21. Public spending on childcare and pre-primary education, 2009

As a percentage of GDP

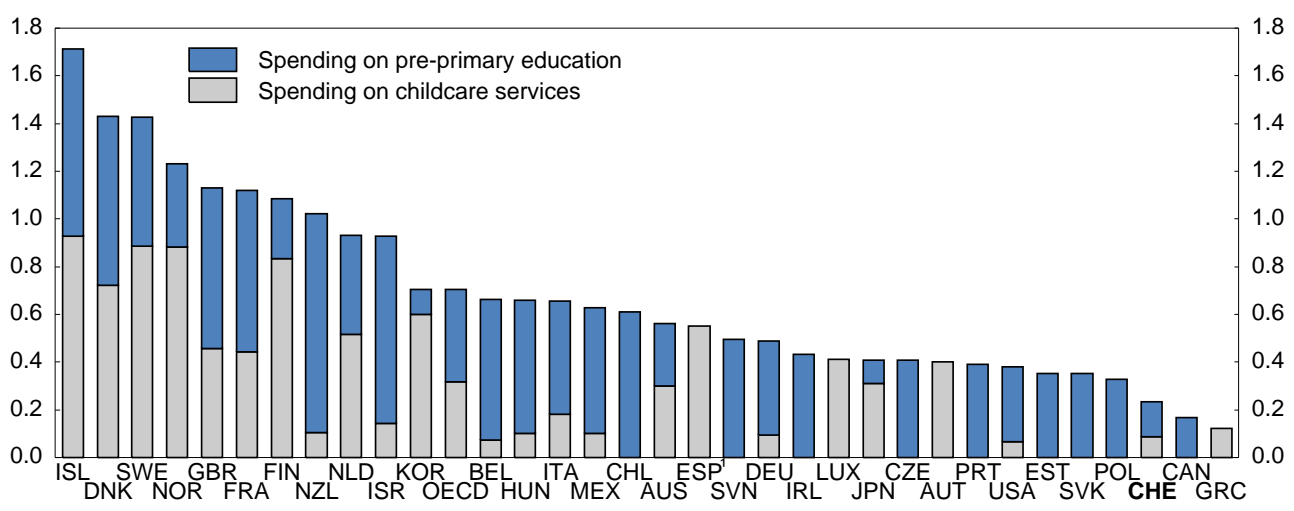

1. Disaggregated spending data are not available for Spain. Note that expenditure data on childcare across the OECD are unlikely to include all local government spending, as local authorities may not report such outlays centrally. Hence, the data in this chart are likely to underestimate public spending on childcare, particularly in federal countries such as Canada and Switzerland.

Source: OECD Family database.

Since the early 1990s substantial progress has been made. From 1991 to 2008 the number of childcare facilities rose from 545 to 1808 at the national level, a near quadrupling in the number of such facilities per 1000 children (Figure 22). According to the Swiss federal government, the national financial assistance programme that took effect in 2004 contributed to the creation of 39500 places, which corresponds to $79 \%$ of the increase in the supply during this period. However, because of the strong increase in demand that paralleled the increase in women's participation rate, there are still important supply shortages for Swiss families. Due to high demand, the assistance programme, which was initially meant to last eight years, has been extended for four additional years. At the regional level, some cantons have revised their legislation and introduced or increased public subsidies. According to the FSO, the use of extra-family childcare services has grown in recent years: $40 \%$ of households with a youngest child under 15 used such services in 2009 , up from $30 \%$ in 2001 . This increase is particularly marked in the case of institutional services such as day nurseries, full-time schools, supervised lunch programmes or out-of-school centres. Some innovative initiatives have also been taken at the cantonal level, such as the contributions by employers to cantonal funds that subsidise childcare facilities in Vaud, Neuchâtel and Fribourg, and at local level, such as childcare vouchers in the Lucerne area (Box 6). Enhanced childcare options would also foster the integration of children from immigrant backgrounds while facilitating mothers' access to the labour market. 
ECO/WKP(2014)40

Figure 22. Number of childcare facilities per 1000 children less than 7 years old by canton

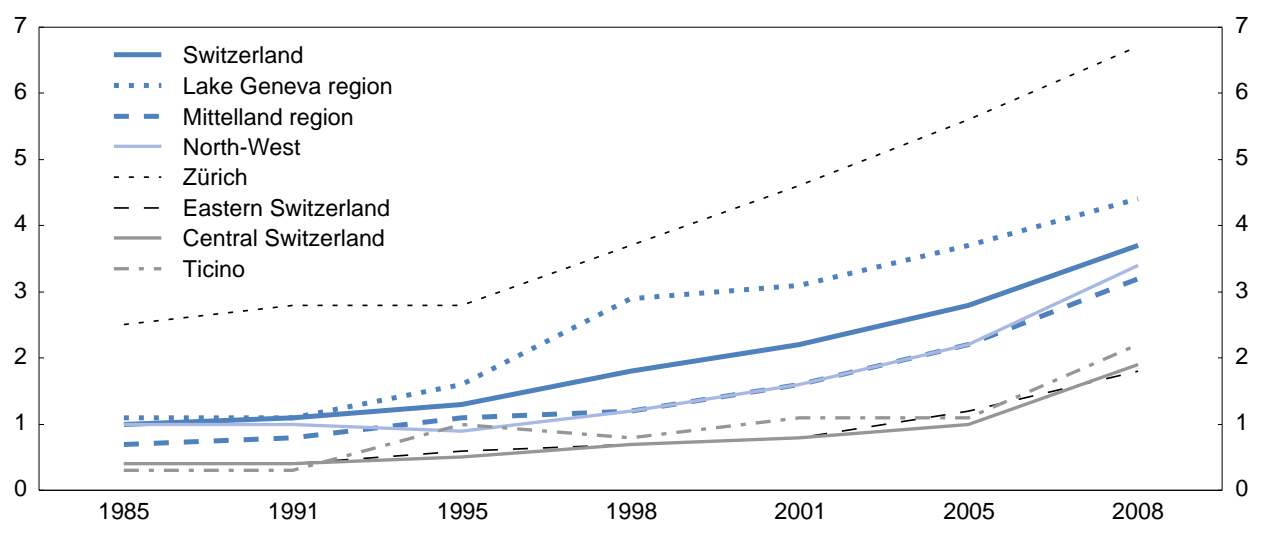

Source: FSO.

\section{Box 6. Childcare vouchers in the Lucerne area}

In the cantons of Vaud, Neuchâtel and Fribourg, as noted, employers contribute to a fund, that afterwards partially finances child care places. Since 2007, more than 6000 places for children day care were created in the canton of Vaud. But other original initiatives have taken place. Three municipalities in the canton of Lucerne took part in what was originally a pilot study that started in 2009 in order to test a system of vouchers for childcare services. Instead of subsidies paid to the childcare institutions, the families received vouchers that they could spend on childcare services provided by a certain number of institutions in the area. The main advantages of this voucher system are: $i$ ) to allow equal opportunities to all families with respect to the public support of childcare, and $i i)$ to increase the range of childcare services parents can choose. Also, using vouchers instead of producer subsidies should enhance competition among providers, given that parents can freely choose their preferred provider.

According to a report by Interface (Müller et al., 2010), a Lucerne consultancy which did an evaluation of the pilot programme in one municipality, the system was well received by the parents as well as by the childcare institutions, and there were no major implementation problems. Most importantly, cost-benefit calculations showed that the additional outlays by the municipality in form of the vouchers were a good investment, under the assumption that families were able to generate additional income as a consequence of the increased childcare supply. In addition, the fact that families were all treated in the same way and that they can freely choose from a certain number of institutions was much appreciated by the involved parties. The system has now been fully implemented in all three municipalities.

Source: Müller et al. (2010).

The high cost of childcare is a second major impediment to better access to the job market and a more fulfilling professional life for women. Region-based modelling of childcare costs shows that Zurich has one of the most expensive childcare systems in the OECD for the couples each earning $100 \%$ of average income, though it is lower ranked for those on lower incomes (Figure 23). According to a 2012 study mandated by the Federal Insurance Office (OFAS, 2012), 27\% of the mothers who gave up paid work did so because of problems in reconciling work and family life. The problems cited were the high price of childcare places, difficulties in finding such places and employers not agreeing to reduce working hours. It is then of primary importance for the Swiss authorities to seek to increase the number of childcare places, which should also reduce their cost by bringing supply closer to demand. But given that a large share of the 
Figure 23. Out-of-pocket childcare costs for a couple family: full-time care at a typical childcare centre ${ }^{1}$

Childcare-related costs and benefits, as a percentage of AW, 2008

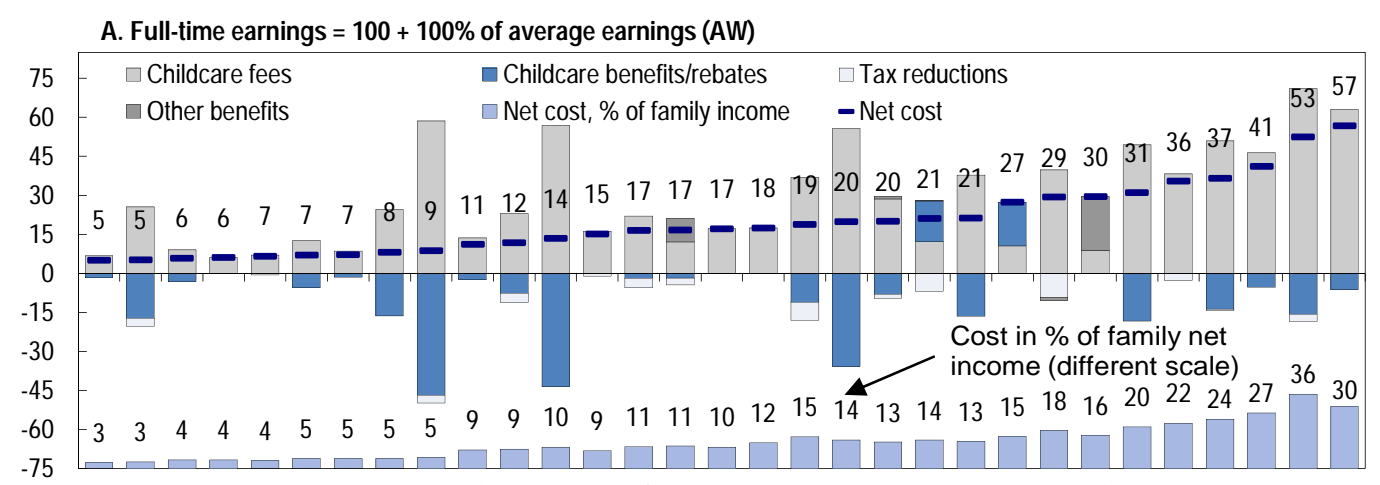

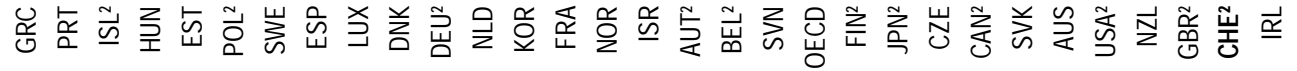
B. Full-time earnings $=100+50 \%$ of average earnings (AW)

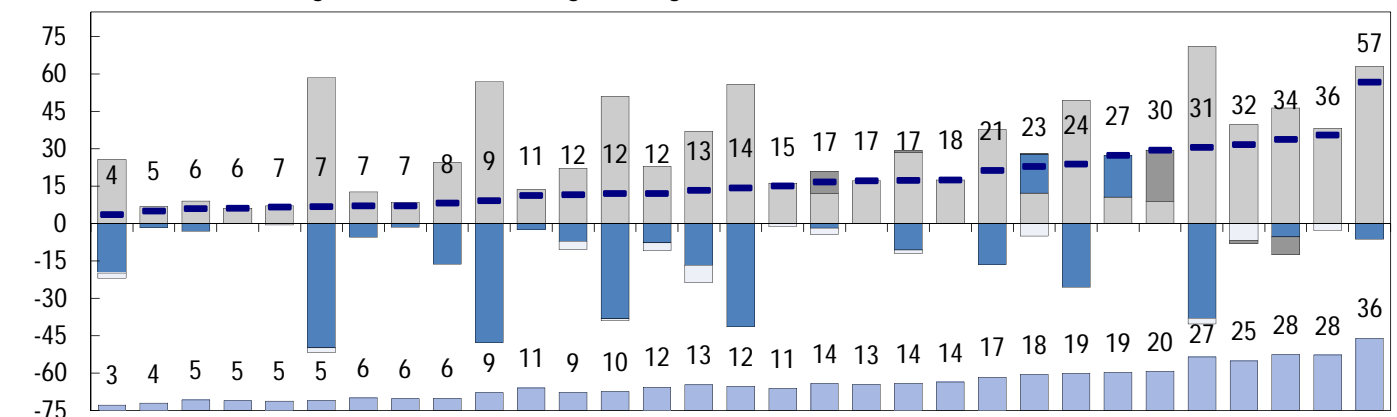

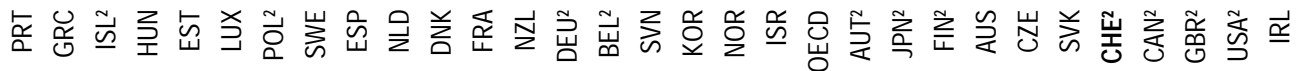
C. Full-time earnings $=67+50 \%$ of average earnings (AW)

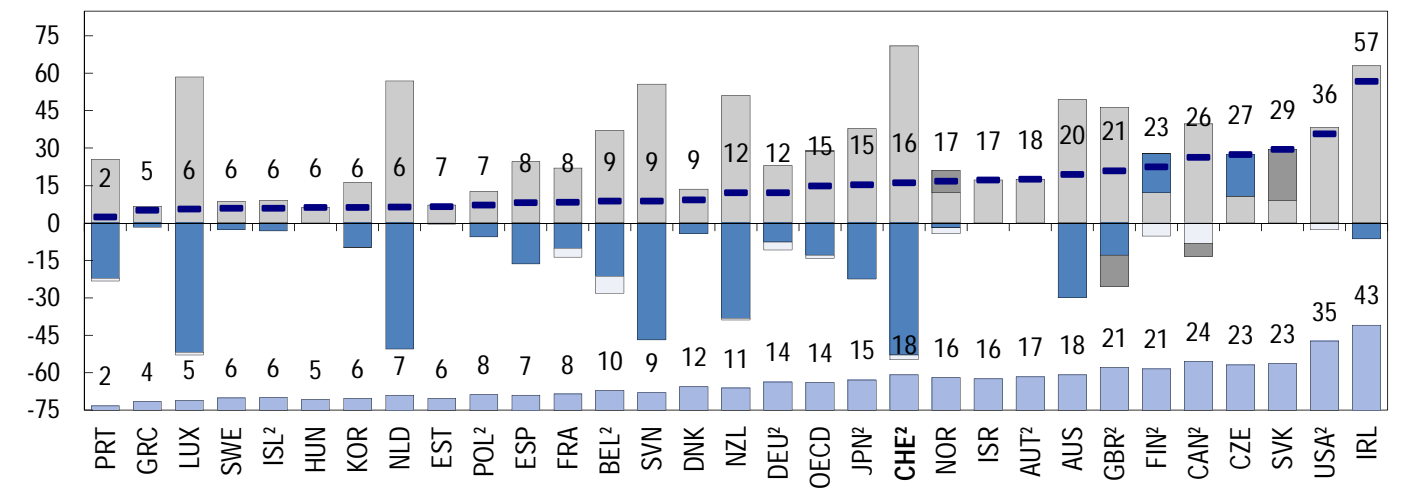

1. The out-of-pocket cost of centre based childcare (or net cost of childcare) is calculated as the difference in "family net income" of a family who uses centre based childcare and an otherwise identical family who does not. "Family net income" is the sum of gross earnings plus cash benefits minus taxes and social contributions. All fee reductions, including free pre-school or childcare for certain age-groups, are shown as rebates where possible. Costs as a per cent of net family income are relative to pre-childcare income.

2. Modelling of childcare costs is region specific rather than at the national level. The regions used for Switzerland is the city of Zurich.

Source: OECD Tax-Benefit models. 
costs are staff related, if the government (cantons and communes) wishes to boost provision, it faces a trade-off of increasing direct public spending on additional facilities against allowing a broader range of price and quality options when setting the sector's regulatory requirements.

Another important aspect of work-life balance for women is the extent to which household work is shared equitably at home. In 2013 combined weekly hours of paid and unpaid work were roughly equal for men and women (all men and women aged 15 to legal retirement age: 63 for women and 64 for men), with 50.8 hours for men and 49.7 hours for women (Figure 24). These numbers are not too different from what they were back in 1997: 50.7 hours for men and 51.3 hours for women. The split between the two types differs significantly between sexes, however. While men spent about $66 \%$ of this time on paid work in 2013, that share was only 41\% for women. They had been 69\% and 36\%, respectively, in 1997 .

Figure 24. Paid and household work

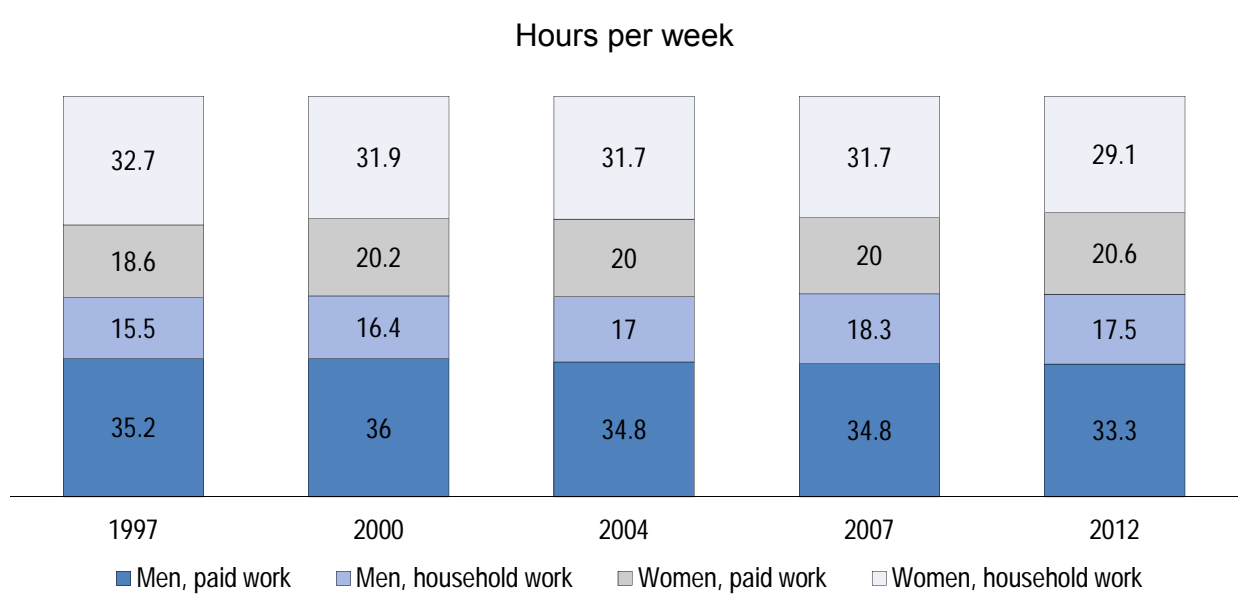

Source: FSO.

While such differences in time allocation between paid and unpaid work may reflect personal preferences, domestic work has a negative effect on female labour supply and therefore on female career opportunities and expected lifetime salaries. While increasing paid work offers opportunities of promotion and higher wages, more housework does not. Greater participation of men in unpaid work would facilitate more intensive female labour force participation (hours and numbers), a better use of the talent pool and, arguably, better child development. One of the direct policy levers here is leave, and Switzerland is one of the few countries without part-time work entitlements. Introducing time-limited entitlements to part-time work for parents with young children, especially fathers since the incidence of part-time work is already high among women, as in Australia and Austria would help bring a more balanced sharing of paid and household work in the family.

Partly because household work is not priced, the split between paid and household work translates into the contribution of each sex to total household income. In a childless couple the average contribution to total household income of the female partner is about $35 \%$. This share typically falls as the number of children in the family rises, dropping to $18 \%$ on average in a household with three children (Figure 25). Because the difference in financial contribution is greater than the difference in time contribution, another explanation for these figures is the gender wage gap, discussed in the next section. 
Figure 25. Percentage contribution to total household income, by type of household

2004

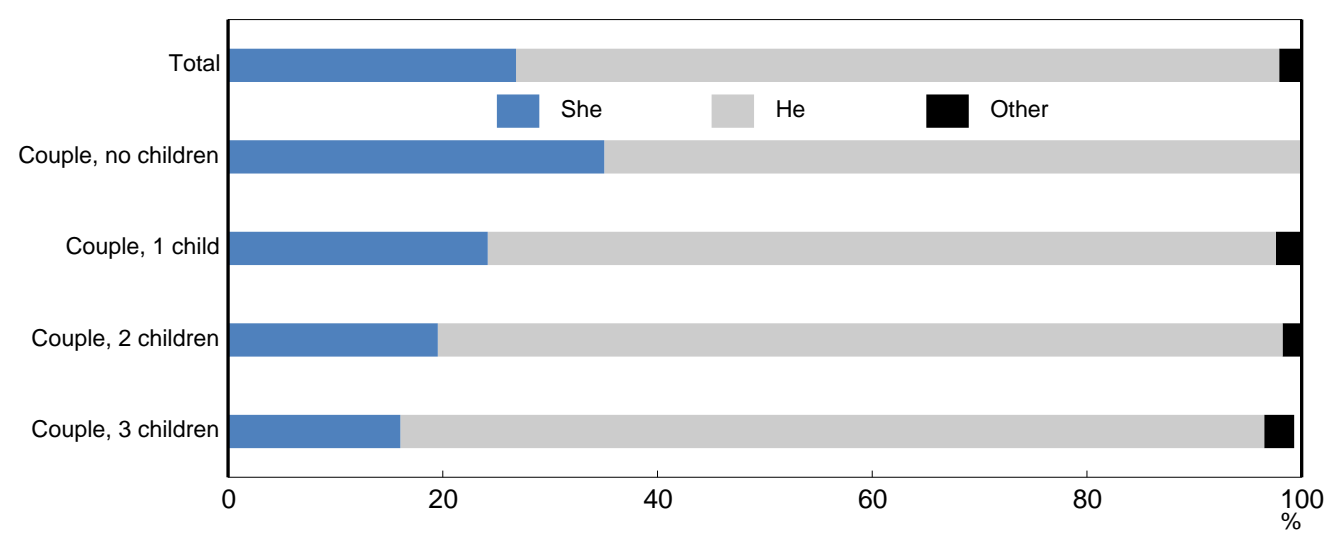

Source: FSO.

The difficulty for Swiss women to organise a sustainable childcare solution is made worse by the low level of leave entitlements for parents following the birth of a child. Maternity leave is 14 weeks (under the Code of Obligations), with financial compensation also lasting 14 weeks (Loi fédérale sur les allocations pour pertes de gain). There is also protection against dismissal for 16 weeks after the birth, in the form of a compensatory payment (Article 5 of the Gender Equality Act). But there exists no employment guarantee by law after that leave. In addition, there is no federally granted statutory paternity or parental leave that could facilitate mothers' post-maternity reintegration into the labour force. Introducing paternity leave, or take-it-or-leave-it parental leave to be divided between parents consecutively could help dissuading mothers from staying out of the job market too long.

\section{Taxation and work incentives}

Tax incentives are another important factor behind the high level of part-time work among Swiss women, since the entire tax/benefit system is means tested. As explained in Box 7 below, labour supply by the second income earner in married couples in Switzerland, typically the wife, is discouraged by high implicit marginal income tax rates, also known as the "marriage penalty". Tax declarations based on the household rather than the individual play a major role in this penalty with increments to household income taxed at higher rates than under separate taxation. In the federal income tax, the Swiss government has recently introduced a tax deduction for childcare costs and has adopted measures in order to remove much of the marriage penalty. In 2012, the Swiss Federal Council launched a consultation process on a federal law aimed at eliminating, within the framework of direct federal tax, the penalty for married couples. 
ECO/WKP(2014)40

\section{Box 7. High marginal income tax rate for the second earner}

Due to the fact that there are additional tax allowances for couples that are not available to singles, the comparison between married couples and two singles living together on the basis of the same taxable income does not correspond to the situation where the married couple and the two singles have the same joint gross income. Therefore the table below contains estimates of the federal tax component of the tax wedge based on 1) equal gross income or 2) equal taxable income.

Table 3. High marginal tax rate for the second earner

\begin{tabular}{|c|c|c|c|c|}
\hline & $\begin{array}{l}\text { Gross } \\
\text { earnings }\end{array}$ & $\begin{array}{c}\text { Tax } \\
\text { allowances }\end{array}$ & $\begin{array}{l}\text { Taxable } \\
\text { income }\end{array}$ & $\begin{array}{c}\text { Final } \\
\text { income tax }\end{array}$ \\
\hline & \multicolumn{4}{|c|}{ Estimates based on equal gross income } \\
\hline Couple 50/50 & 100000 & 37400 & 62600 & 502 \\
\hline Single & 50000 & 10650 & 39300 & 199 \\
\hline Single & 50000 & 10650 & 39300 & 199 \\
\hline Combined & 100000 & 21300 & 78600 & 399 \\
\hline Couple $70 / 30$ & 100000 & 37400 & 62600 & 502 \\
\hline Single & 70000 & 13430 & 56500 & 621 \\
\hline Single & 30000 & 7870 & 22100 & 59 \\
\hline \multirow[t]{2}{*}{ Combined } & 100000 & 21300 & 78600 & 679 \\
\hline & \multicolumn{4}{|c|}{ Estimates based on equal taxable income } \\
\hline Couple 50/50 & 143500 & 43482 & 100000 & 1968 \\
\hline Single & 62400 & 12374 & 50000 & 445 \\
\hline Single & 62400 & 12374 & 50000 & 445 \\
\hline Combined & 124800 & 24747 & 100000 & 890 \\
\hline Couple $70 / 30$ & 144500 & 44432 & 100000 & 1968 \\
\hline Single & 86200 & 16106 & 70000 & 1022 \\
\hline Single & 39200 & 9149 & 30000 & 119 \\
\hline Combined & 125400 & 25255 & 100000 & 1141 \\
\hline
\end{tabular}

Source: OECD calculations

\section{Women's experience with unemployment and poverty}

Women and men in Switzerland are affected differently by poverty and unemployment. The share of poor people (those whose disposable household income is below the defined poverty line) is higher among women than among men, though the difference is not large for the entire population: $8.8 \%$ for women versus $7 \%$ for men in 2010 . When looking at the economically active population, however, $4.8 \%$ of women are poor, but just $2.5 \%$ of men are. Among those with the highest risk of poverty are single-parent families, especially those headed by women, and elderly women.

The unemployment rate has long been higher for women than for men. Men, however, tend to be hit harder by economic crises than women, and more generally male unemployment tends to be more responsive to the business cycle. This is evidenced by the last crisis. Taking August 2008 as a benchmark, men have been faring worse than women (Figure 26). In March 2014 men's unemployment rate was 67\% above its pre-crisis level, compared to a rise of $27 \%$ for women. The fact that private industry was hit 
hardest and the government sector was rather protected in the last recession explains why men have suffered more. In its aftermath, public stimulus spending was targeted mostly to male-dominated sectors, while tax cuts for families and married couples were intended to boost consumption, thereby impacting mostly retail, tourism and restaurants where female employment is dominant (SECO, 2012). In addition, because men are still over-represented in goods production, they often need to go through retraining programmes to meet the new realities of the job market. By contrast, women, who traditionally choose to work in the tertiary sector, find it easier to adapt to services' increasing role in developed economies.

Figure 26. Women's unemployment is higher, but men's is more responsive to business fluctuations

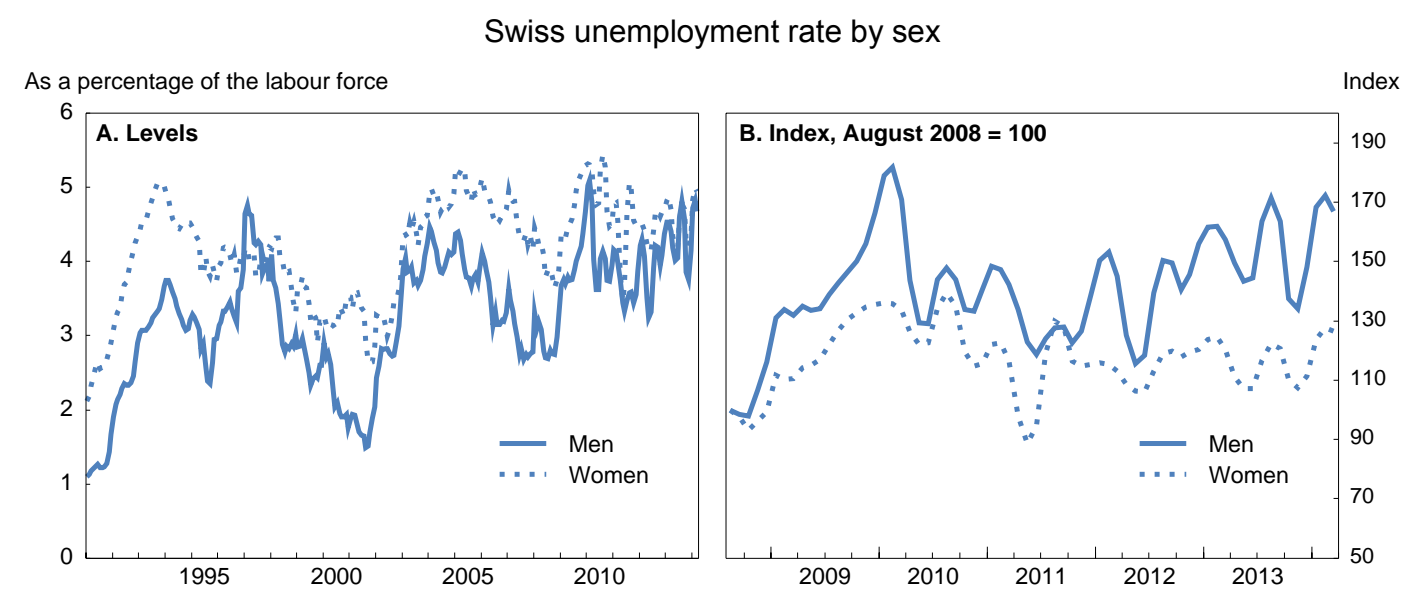

Source: FSO.

\section{Box 8. Recommendations for a better reconciliation between work and family life}

- Increase women's labour-market options by increasing public spending on childcare and out-of-school-hours care and by setting applicable regulations to enhance the range of available price-quality choices.

- Remove the so-called marriage tax penalty at the federal level by introducing individual, as opposed to family, taxation or some equivalent measure.

- $\quad$ Create paternity leave, and consecutive "take-it-or-leave-it" parental leave to be shared between fathers and mothers.

- Introduce a time-limited entitlement to part-time work for parents with very young children

\section{Reducing the wage gap}

For the same occupation and number of hours worked, women are generally paid less than men. The gap has narrowed over the last decade, albeit at a slower pace in recent years. While some two thirds of the gap can be explained by observable factors such as differences in education, position, skills and experience, a third remains unexplained and possibly attributable to discrimination. This section reviews the Swiss gender pay gap, the progress that has been made in reining it in and what remains to be done.

In Switzerland the gross gap (not adjusted for observable differences) started closing in the 1960s and was most recently 18.9\%, down from 23.7\% in 1994 (according to the Swiss Earnings Structure Survey; Figure 27). The pace of the reduction in the gap has been relatively modest, however, with women gaining 
an extra one tenth of a percentage point pay rise over men on average since 1942 (Bureau of Federal Statistics, Salaires et revenus du travail - Données détaillées). The catch-up accelerated between the mid-1990s and the mid-2000s from which point on it stagnated.

\section{Figure 27. Difference between male and female wages (gross gap)}

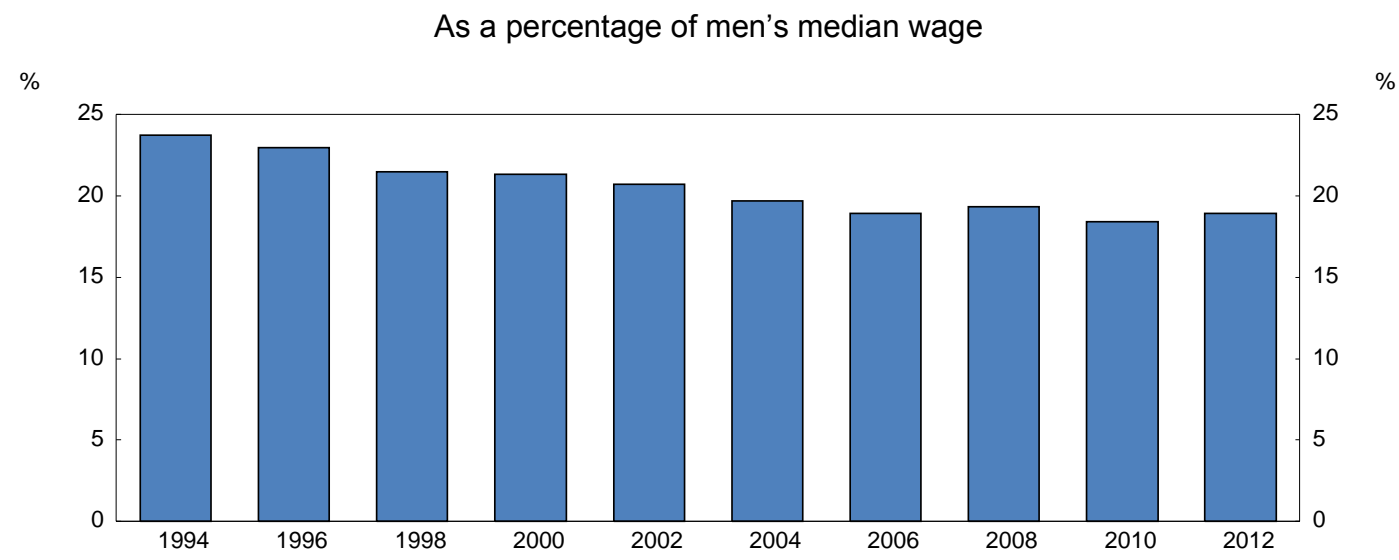

Source: FSO.

Almost all OECD countries have legislated some form of equal pay for equal work, but gender wage gaps persist. While receding, the OECD average gross gender pay gap is still $15 \%$. Cross-country variation in the size of the gap are significant, ranging from a low of 5-8\% for countries like Hungary, New Zealand and Norway, up to $29 \%$ for Japan and $39 \%$ for Korea at the other end of the spectrum (Figure 28). Switzerland does relatively poorly both in terms of the level of the gap and the decline over the last decade.

In many countries the wage gap is larger at the median than at the bottom of the pay scale. In Switzerland there is considerable differences in men's and women's pay across occupations even after taking into account the different full-time and part-time compositional effects across genders (Table 4). At the level of management, where the full-time and part-time compositional effect is minimal, the gender pay gap is particularly pronounced. Indeed the wage gap is higher the more senior the management position (FSO, 2013). Among full time workers the percentage of men in the highest annual income bracket - more than CHF 104000 - is twice as big as the percentage of women (27\% and $13 \%$, respectively), while their share among those earning less than half that much was much smaller (9\%, compared to $24 \%$ ) (Figure 29). It is only for administrative staff and apprentices that the wage gap is much smaller than average. Box 9 provides evidence that wage discrimination may set in right after apprenticeship. 
Figure 28. Trends in gross gender pay gaps
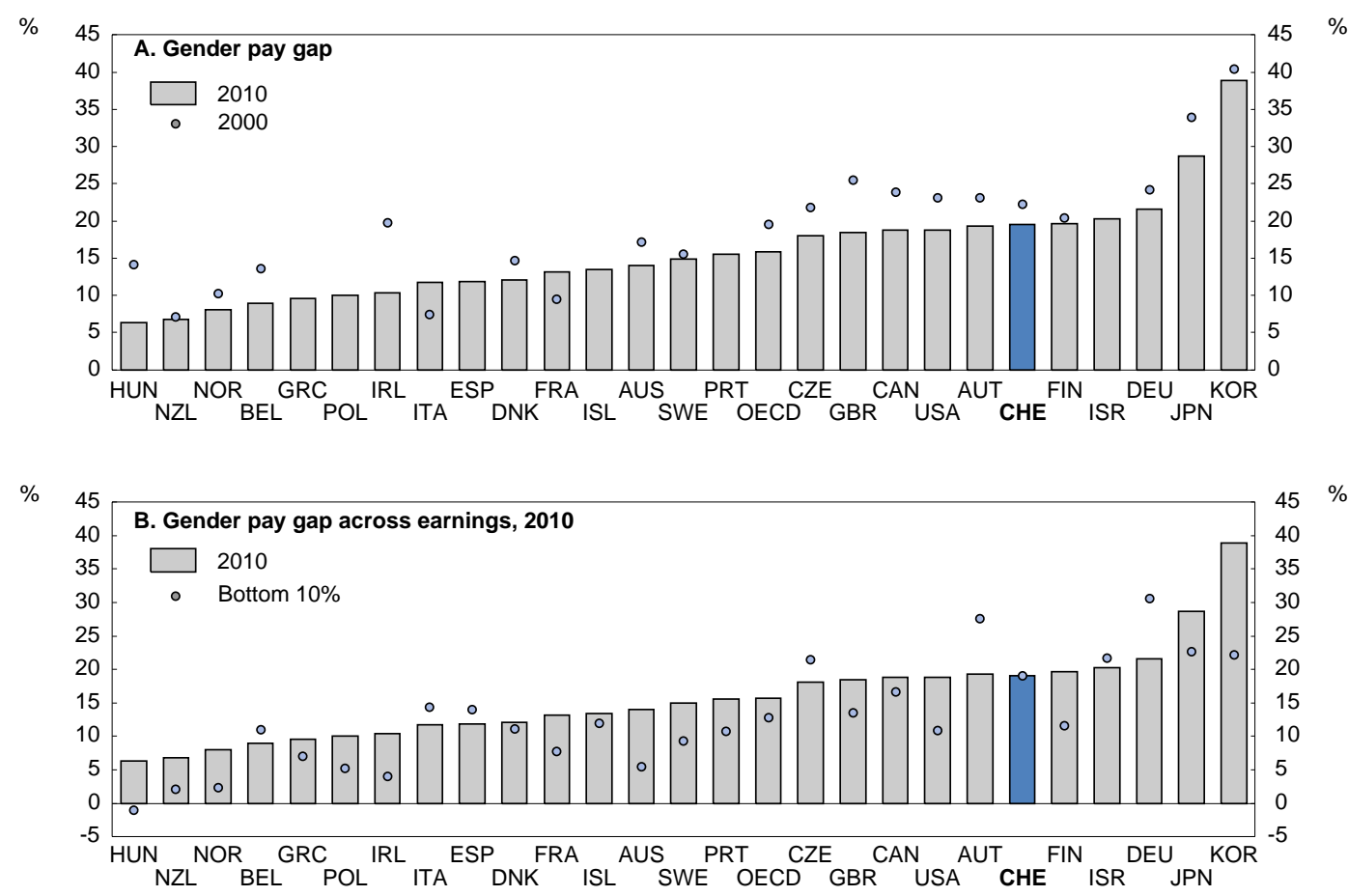

1. Defined as the difference between male and female median wages divided by male median wages. Data refer to 2009 (instead of 2010) for Ireland, Denmark, Sweden, the Czech Republic, Austria, Switzerland, Finland, Israel, Germany, Korea and to 2008 for Belgium, France, Greece, Iceland, Italy, Poland, Portugal, Spain; and to 1999 (instead of 2000) for the Czech Republic.

Source: European LFS, 2010; Current Population Survey, March 2009, for the United States; OECD Employment Database.

Table 4. Gross gender pay gaps by economic activity status and occupation, 2011

Gross annual employment income in francs

\begin{tabular}{|c|c|c|c|c|c|c|}
\hline & \multicolumn{2}{|c|}{$\begin{array}{c}\text { Full-time } \\
(90 \% \text { and more })\end{array}$} & \multirow[t]{2}{*}{$\underset{\%}{\text { Gap }}$} & \multicolumn{2}{|c|}{$\begin{array}{c}\text { Part-time } \\
\text { (less than } 90 \% \text { ) }\end{array}$} & \multirow[t]{2}{*}{$\begin{array}{c}\text { Gap } \\
\%\end{array}$} \\
\hline & Men & Women & & Men & Women & \\
\hline Self-employed & 87800 & 59800 & 31.9 & 42000 & 27600 & 34.3 \\
\hline Family workers & 63800 & 48600 & 23.8 & 17700 & 22800 & -28.8 \\
\hline Employees & 84500 & 68900 & 18.5 & 43800 & 34800 & 20.5 \\
\hline Executives, senior managers & 129400 & 101800 & 21.3 & 60000 & 52000 & 13.3 \\
\hline Academic/scientific professions & 110000 & 88400 & 19.6 & 64700 & 50900 & 21.3 \\
\hline Intermediate professions & 93800 & 75000 & 20.0 & 46200 & 43400 & 6.1 \\
\hline Administrative staff & 75600 & 70200 & 7.1 & 35700 & 37500 & -5.0 \\
\hline Service and sales staff & 72000 & 53800 & 25.3 & 24500 & 25300 & -3.3 \\
\hline Craftsmen and skilled workers & 71600 & 54400 & 24.0 & 46500 & 26000 & 44.1 \\
\hline Drivers and fitters & 70500 & 51400 & 27.1 & 28300 & 26000 & 8.1 \\
\hline Unskilled workers & 63300 & 48800 & 22.9 & 13500 & 14000 & -6.7 \\
\hline Apprentices & 12400 & 11700 & 5.6 & - & - & - \\
\hline Of which: First year & 9100 & 8600 & 5.5 & - & - & - \\
\hline Second year & 11700 & 11900 & -1.7 & - & - & - \\
\hline Third and fourth years & 14400 & 15000 & -4.2 & - & - & - \\
\hline
\end{tabular}

Source: FSO, wages and income from employment, indicators. 
ECO/WKP(2014)40

Figure 29. Employed persons by brackets of annual gross employment income in francs, 2011

Per cent

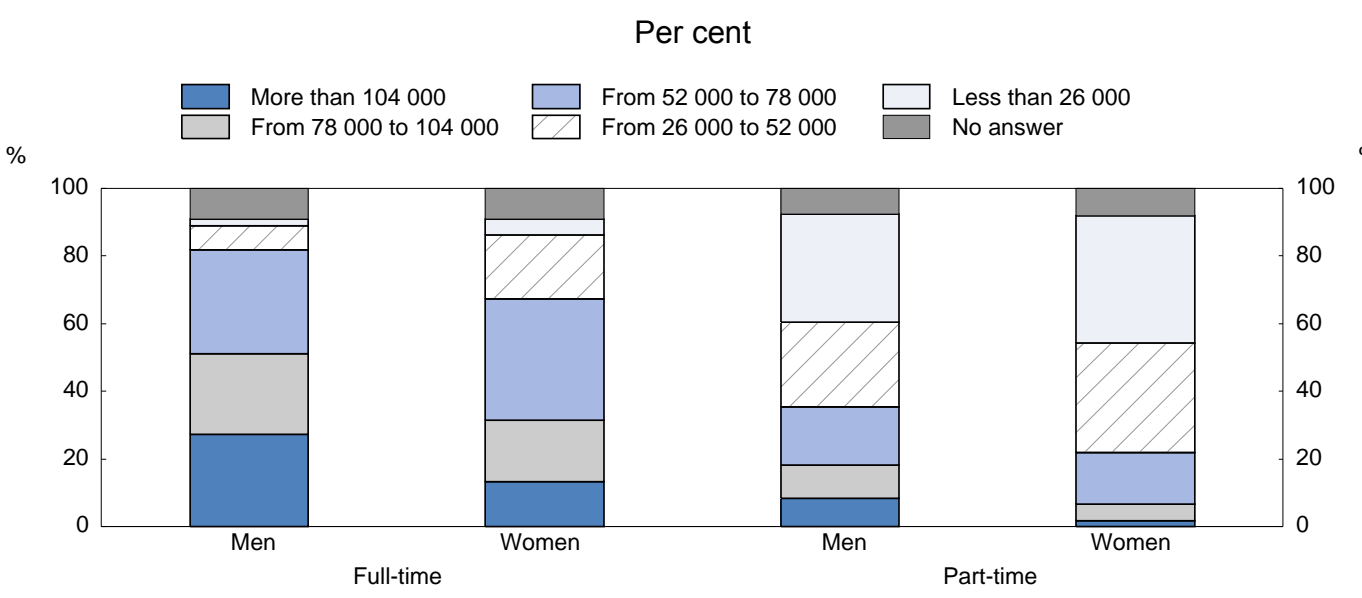

Source: FSO.

\section{Box 9. Does wage discrimination start right after school? Data from the TREE study}

As Table 4 indicates, salary differences between men and women are insignificant for apprentices. A natural question is then when do women's salaries start to fall behind?

From 2000 to 2010 the Swiss National Science Foundation and the University of Basel conducted a panel study of approximately 6000 young people who had participated in the 2000 PISA survey and had left compulsory school that year. This sample was followed up by TREE (Transitions from Education to Employment) through seven annual survey panels between 2001 and 2007 and an eighth in 2010. It is the first longitudinal survey in Switzerland to address issues concerning the transition from youth to young adulthood at national level, paying special attention to their paths of education and employment following compulsory education.

The TREE study reports several interesting findings. While it confirms higher tertiary education rates for women than for men $(27 \%$ vs. $18 \%)$, it also points to early signs of discrimination. While differences in observables are presumably smaller at a younger age, on average women with an upper secondary diploma already earned CHF 500 per month less than their male counterparts. The average difference is only CHF 100 for those without upper secondary education, however, generating an overall average gap of CHF 400 , which corresponds to a $9.5 \%$ difference, slightly higher than estimations of the net wage gap in Switzerland (around 7\%). The wage gap is also more pronounced in the French/Italian-speaking cantons (14\%) than in the German-speaking region (9\%). Fully $15 \%$ of the young women first entering the labour market settle for a monthly wage in the lowest bracket (less than CHF 3000 ); only $6 \%$ of the young men reported working for such pay (Figure 30). Finally, men tended to stay at their parental home longer, since $49 \%$ of women had left home, but only $28 \%$ of men had done so.

\section{Figure 30. Distribution of starting wage by gender}

Per cent, 2010

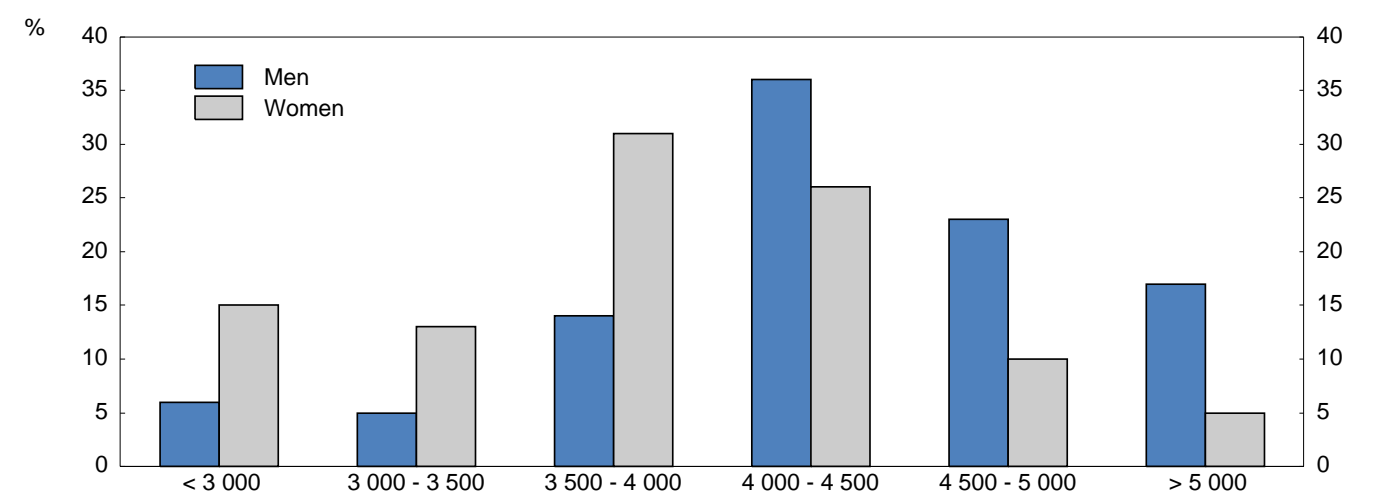

Source: SWN and University of Basel, Young people in transition from education to the labour market (TREE study). 
As far as Switzerland is concerned, the gender pay gap problem seems to be even more variable across sectors than across occupations (see Table 4 and Figure 31). Financial services top the ranking with a gross gap of $48.0 \%$, followed by electric products manufacturing (38.2\%) and insurance (35.4\%). At the lower end of the spectrum there is almost no difference for postal employees and only a $7 \%$ difference in the extractive industry and in construction. Around the national average are sectors such as retail trade, education and real estate. As first noted by Becker (1957), increased competition between firms pushes down the wage gap by putting discriminating firms at a disadvantage. Increasing competition, both from domestic and foreign firms, and reducing regulation in the economy, could reduce the Swiss wage gap in sectors where it is largest by encouraging the replacement of old discriminatory habits with a hunt for talent. Several country studies have shown that increased competition does reduce the wage gap. Black and Strahan (2001) shows that the gender wage gap in the US banking industry declined after the deregulation of the industry that started in the mid-1970s. Similarly, Hellerstein et al. (2002) shows that, in plants with high levels of product market power, those employing relatively more women were more profitable. See also Lovász (2008) for recent study about Hungary.

Figure 31. Gross gender wage gaps by sector, 2010

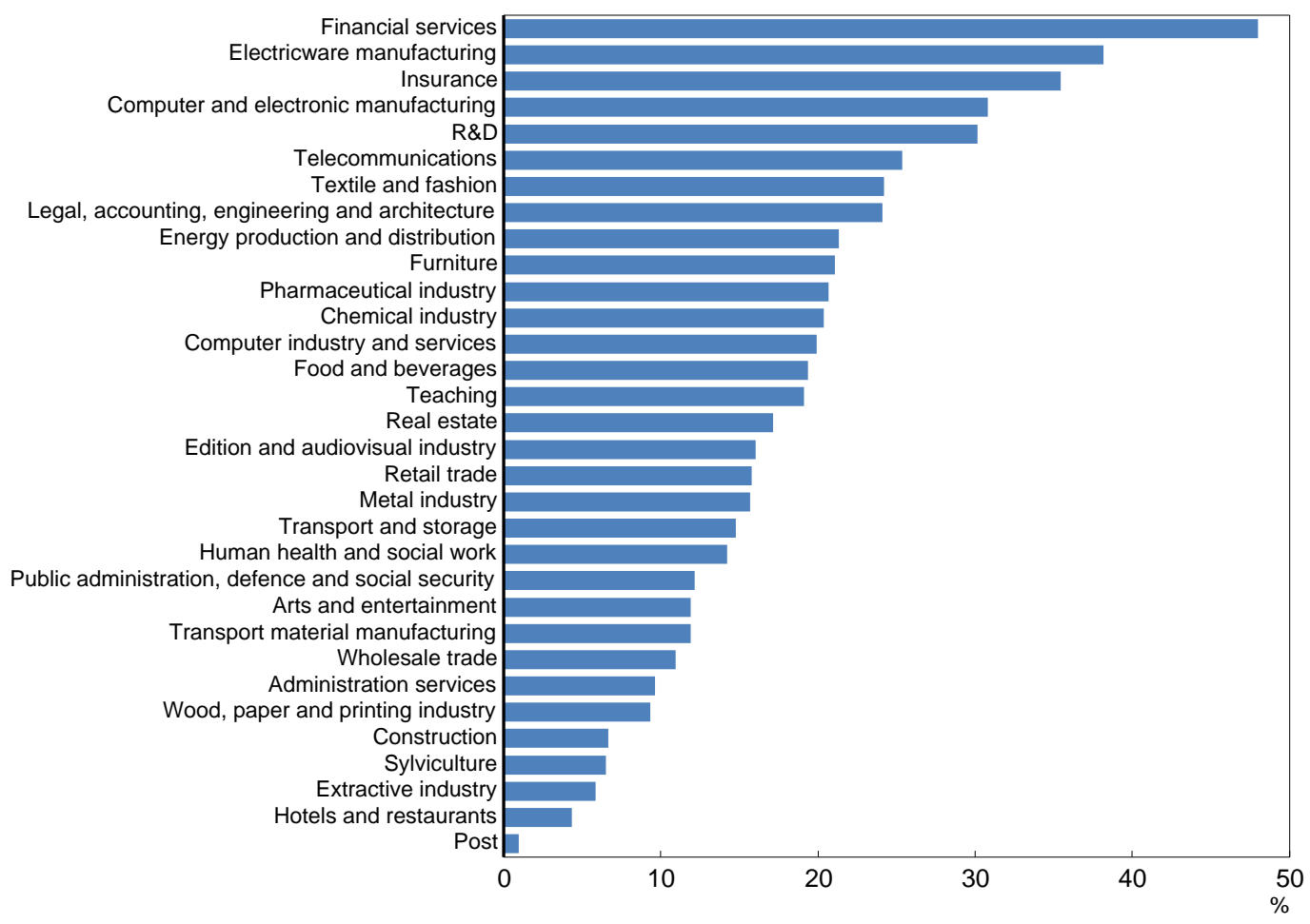

Source: FSO, Swiss Earnings Structure Survey.

Regarding firms' size, the gender pay gap follows a U-shaped relationship: it is greater in small and especially in large companies for whom it has even grown since 1998 (Figure 32, Panel A). Also, the difference is greater for older workers (Panel D) for whom educational attainment gaps by gender are largest, resulting in lower incomes for women already as from their 40s (women born in the 1960s), whereas men's salaries show no such pattern.

As documented in several other places in this article, there exist some differences across regions (Panel B), with the largest wage gaps in Zurich, where they even increased on average between 1998 and 2010 (but this is also the place where financial services are concentrated), and in Tessin, where they have 
decreased at the fastest pace. The Leman region is where the gross gender pay gap is smallest. Finally, the more educated the employee, the bigger the wage gap (Panel C).

Figure 32. Structure of the gross gender pay gap
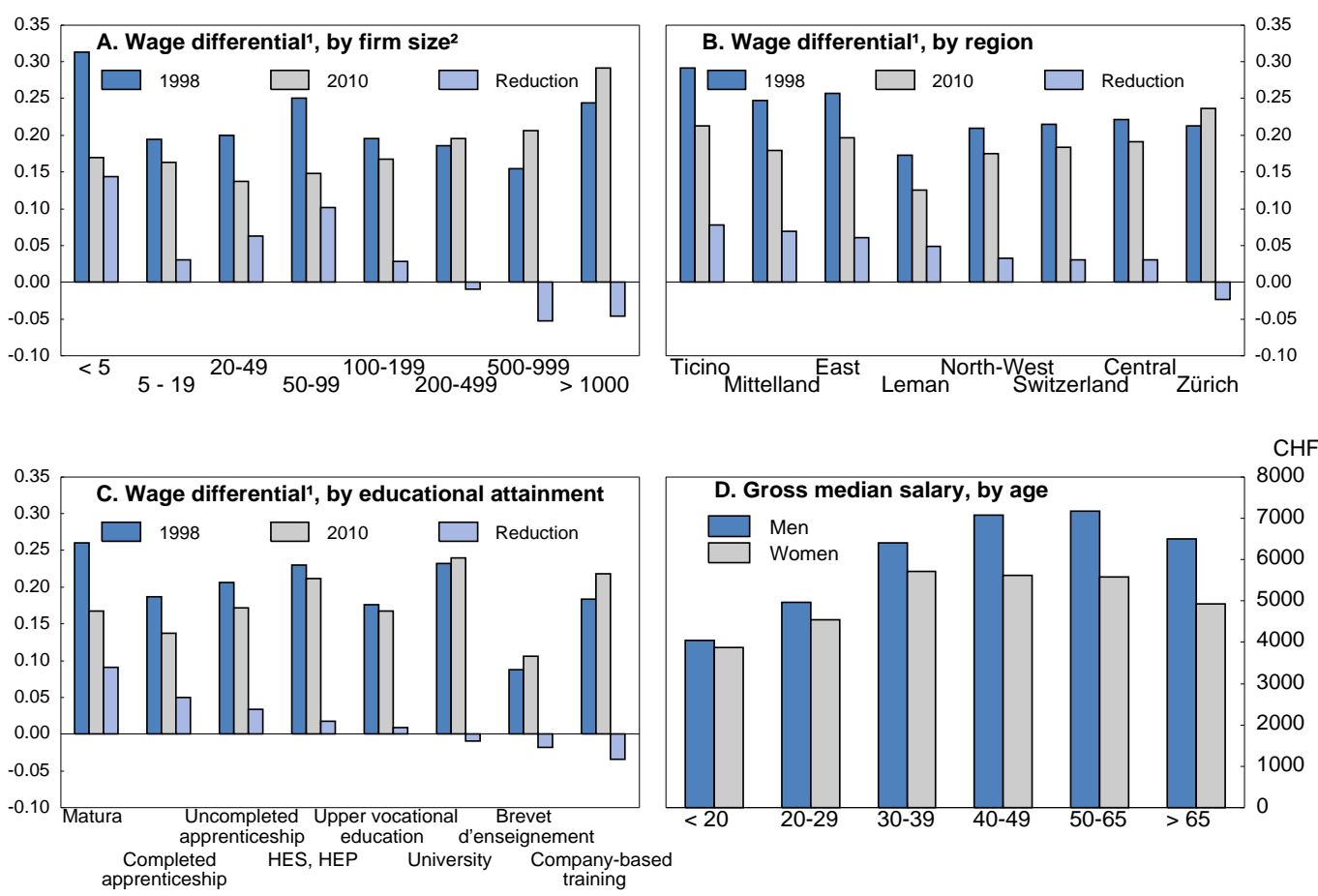

1. As a ratio to the median salary of a male worker.

2. Measured in terms of number of employees.

Source: FSO, Swiss Earnings Structure Survey.

A significant part of the gross gaps can be explained by the structure of jobs across occupations and sectors, as well as educational attainment, work experience and company seniority. In Switzerland the residual (or unexplained part, which corresponds to the net gap) was estimated at 6.9 percentage points in 2010, down from 8.8 in 1998 (NOGA, 2008). This represents $37.6 \%$ of the gross gap. According to the FSO's last update, in the public sector of the Confederation, where salary grids are the norm, that share was lower at 21.6\% (CHF 3108 per annum). Looking across economic branches in the private sector, the net wage gap is greatest in manufacturing and transportation and storage, and lowest in miscellaneous services, the extractive industry and professional, scientific and technical activities (Figure 33). The Swiss Earnings Structure Survey, however, is the only available source of information on the net wage gap. A better understanding of its magnitude can be achieved by encouraging a more diverse set of studies (econometric, experimental) to ascertain the robustness of the estimate and the true amount of gender wage discrimination. Narrowing and ultimately eliminating this gap can follow a number of paths, such as better enforcement of the existing legal framework against wage discrimination and promoting wage transparency. One avenue is to develop tools such the Logib software. It is an equal pay self-test tool developed for the Federal Office for Gender Equality. It allows to review pay policy by entering wage data of a company (of at least 50 employees) and to evaluate whether discrimination based on sex is statistically significant. 
Figure 33. Unexplained share in gender wage gap, or net gap

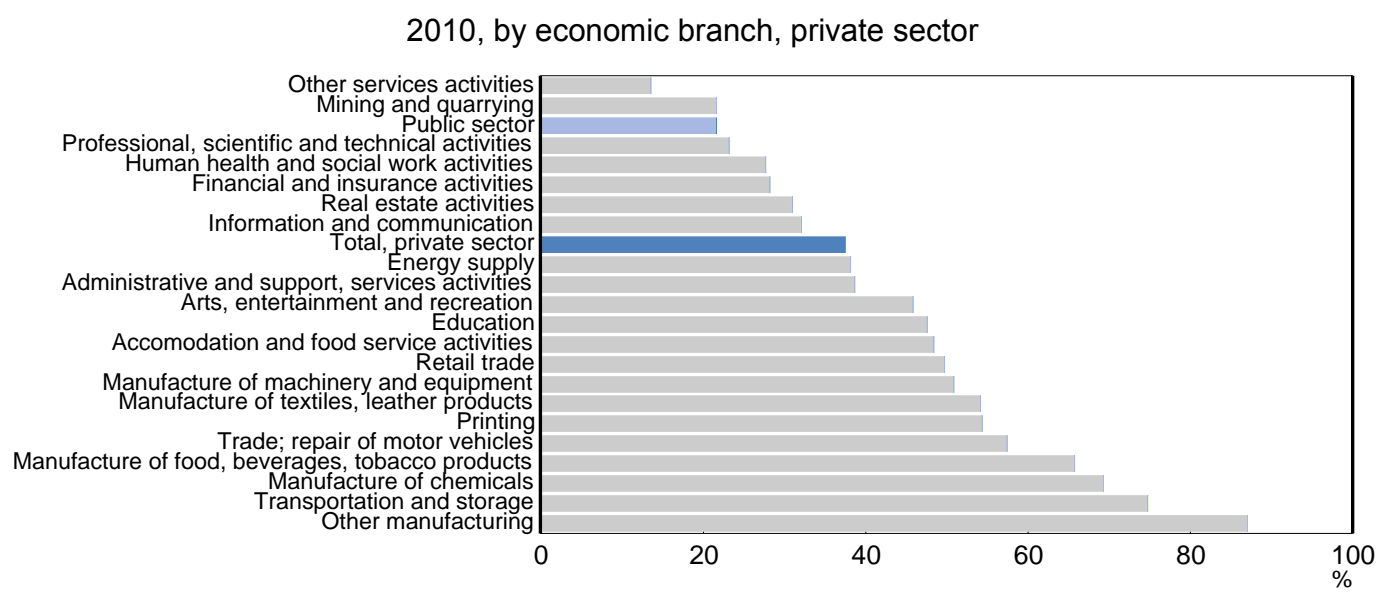

Source: FSO, Swiss Earnings Structure Survey, calculations following Strub and Stocker (2008) who use the Oaxaca-Blinder method.

\section{Box 10. Recommendations for reducing the wage gap}

- $\quad$ Encourage a more diverse set of studies regarding net wage gap calculations.

- $\quad$ Better enforce the existing legal framework against wage discrimination.

- $\quad$ Promote pay transparency.

- Increase competition and reduce regulation in the economy so as to encourage the replacement of old discriminatory habits with a hunt for talent.

\section{Women as entrepreneurs and managers}

Despite impressive progress in female educational attainment in most OECD countries, and a greater role for women in the labour market as documented earlier, women are, with a few exceptions, still significantly underrepresented as entrepreneurs and in leadership positions across OECD countries. While educational attainment is comparable across the sexes, women tend to leave their jobs or fail to move up the hierarchy. As a result, the share of women in managerial or directors' positions does not match their share of the labour force, a phenomenon known as the "leaky pipeline". The last 20 years have seen limited progress on that dimension.

Given that women account for a growing share (in some places a majority) of young graduates, such underrepresentation is a sign of poor human-capital allocation within the Swiss national economy. There are indeed many reasons why, on top of equality, favouring a greater representation of women in those high-stakes jobs should lead to better performance for companies and increased aggregate productivity. First, with increased and costly global competition for leadership talent, companies would gain by more often considering women for top positions. Second, hiring more women in such positions would probably lead to more diverse approaches and solutions to business challenges. Third, many high-growth markets, such as IT, fashion and cosmetics, have a large female customer base and for which insights from female opinion-leaders would benefit the companies involved. Fourth, women in executive roles can serve as models for young aspiring women, creating a virtuous circle of increasing motivation for young women 
and talented leaders for companies. Finally, firms not considered attractive for women risk being seen as having unfriendly work environments and losing out on human talent. See also Box 11 on the effect of gender-diverse boards on governance and performance.

\section{Box 11. The effect of gender-diverse boards on governance and performance: mixed evidence}

The effects of gender diversity on the functioning of boards can be seen in companies' governance and performance. The board of a company is entrusted by shareholders to decide on key issues such as guiding corporate strategy, monitoring management performance and achieving maximum risk-adjusted returns for shareholders, while preventing conflicts of interest and balancing competing demands on the enterprise.

Governance. More gender-diverse boards can contribute to better corporate governance for a multitude of reasons. A heterogeneous board can be a stronger monitor of executive behaviour (Adams and Funk, 2012; Nielsen and Huse, 2010), and a greater number of women directors might bring more independent views into the boardroom and hence strengthen its monitoring function (Rhode and Packel, 2010). Moreover, gender-diverse boards tend to have a wider range of backgrounds, experience, perspectives and problem-solving skills. This richer set of experience and knowledge can be passed on to top managers and potentially improve corporate governance (Terjesen et al., 2009). Carter et al. (2003) and Adams and Ferreira (2009) suggest that more diverse boards are more likely to hold CEOs accountable for poor stock-price performance and encourage better attendance at board meetings, while McKinsey \& Co (2010) found that women are more likely to demonstrate leadership skills, such as staff development, rewards, role models, inspiration and participative decision-making. Brown et al. (2002) suggest that having more women on boards is associated with stronger attention to handling conflicts of interest.

Performance. The economic argument for bringing more women onto boards is based on the proposition that firms that fail to select the most competent candidates for the board of directors damage their financial performance. Catalyst (2008) and McKinsey \& Co (2007 and 2010) assert that better performing firms tend to have more women on their boards. However, this does not prove causality: it cannot be said that more gender-diverse boards generate better firm performance (Terjesen et al., 2009; Coles et al., 2008; and Linck et al., 2008). It may well be that firms with better performance are more likely to seek women. Moreover, the effects of more balanced boards may vary across firms: some firms no doubt benefit from more diversity, others may not (Adams and Ferreira, 2009).After controlling for various firm characteristics - including firm and board size, industry, share of internal board members and others Carter et al. (2003) found a positive relationship between the presence of women on the board and Tobin's Q (the ratio of the market value of a firm to the replacement cost of its assets) for a sample of Fortune 1000 US firms. Other country-specific studies have found higher volatility in stock returns of firms with lower proportions of women directors (Adams and Ferreira, 2004). However, there are also studies that find no, or a negative, relationship between women on the board and firm financial performance (Böhren and Ström, 2005; Rose, 2007; Lee and James, 2007; Marinova et al., 2010; and, Randøy et al., 2006). In the only study on the effects of the first years of the implementation of Norway's quota system (2001 to 2009) aiming at gender-diverse boards, Ahern and Dittmar (2012) found that the constraint imposed by the quota caused a significant drop in stock prices at the announcement of the law and a large decline in Tobin's $Q$ over the following years, consistent with the idea that firms had already chosen boards to maximise value. The law was voted in 2003 and became compulsory in 2006, however, leaving only a few years to evaluate its effect. The value loss was not caused by the sex, but the quota led to younger and less experienced boards, increases in leverage and acquisitions, and deterioration in operating performance.

\section{The leaky pipeline}

The share of women in the labour force has risen continuously over time to between 40 and $50 \%$ in most OECD countries (Figure 34). Their share in senior management positions, however, does not reflect this aggregate trend. In the OECD today women represent less than one third (32\%) of managers, slightly below Switzerland's share of 33\%, up from 29\% in 1996. Few OECD countries have anything like the same proportion of women in the labour force as in senior management positions. Looking at the situation in Switzerland, most of the (modest) catch-up was made from 1996 to 2002 (+3.8 percentage points), with little change since then $(+0.3$ point $)$. 
Figure 34. Women's shares of the labour force and of senior management ${ }^{1}, \mathbf{2 0 1 0}^{2}$

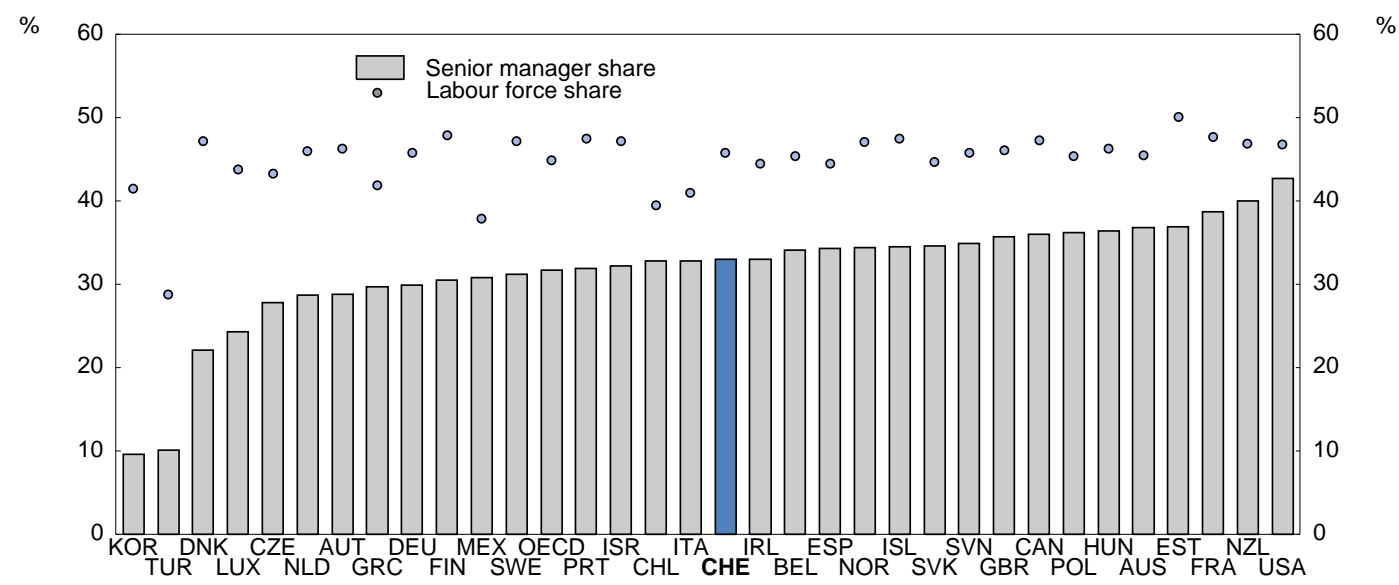

1. Senior managers cover category (1) of the International Standard Classification of Occupations (ISCO), including legislators, senior officials and managers.

2. Senior managers data refer to 2008 for Australia, Canada, Israel, Korea, Mexico, New Zealand and the United States; to 2002 for Chile.

Source: OECD Employment database 2013; ILO.

In recent years the share of women on company boards has nearly doubled in Switzerland, but from a very low starting point. According to the 2012 European Board Diversity Analysis conducted by Egon Zehnder International (2012), 11.6\% of board positions (95 out of 820) in Swiss largest companies (those with market capitalisation greater than EUR 4 billion) were held by women in 2012, up from 5.9\% in 2006 . Nevertheless, that proportion remains only about half those of some Nordic countries or France (Figure 35). According to a 2005-11 study conducted by Credit Suisse (2012) comprising 2360 companies around the world, the most progress was made by European companies including Swiss ones. The study found that large companies and sectors that are closer to final consumer demand, such as

Figure 35. Share of women on company boards of Europe's largest companies, ${ }^{1} 2012$

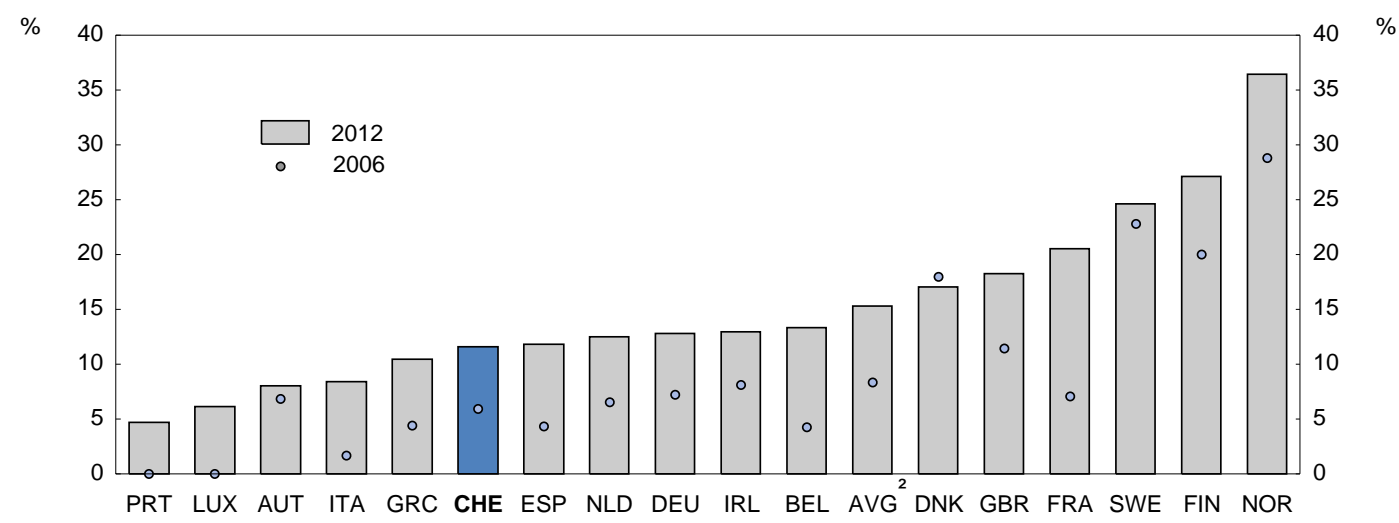

1. With market capitalisation of at least EUR 4 billion.

2. Weighted average across displayed countries.

Source: European Board Diversity Analysis 2012. 
healthcare or financial services, have a greater proportion of women on their boards. When it comes to performance of gender-diverse boards, the study found superior share-price performance for the companies with one or more women on the board. Evidence reviewed by OECD (2012a) is less conclusive, however (Box 11). Unfortunately, no data linking performance and the presence of women on boards are available for Swiss companies. Some countries, such as Norway, have adopted quotas to raise the share of women in leadership positions. As an alternative Sweden has opted for a milder approach based on voluntary commitment (Box 12), as have the United Kingdom and Denmark. The proportion of women on company boards should be increased by setting ambitious targets combined with the "Comply or Explain" practice or by setting quotas.

\section{Box 12. How to succeed without quotas? The Swedish example}

Some countries (Norway, for example) have introduced quotas to force up the share of women in leadership positions. As the 2008 Swedish example shows, other options are available.

In order to increase the share of women on boards, the Swedish Corporate Governance Code states that "The board is to have a composition appropriate to the company's operations, phase of development and other relevant circumstances. It is to exhibit diversity and breadth of qualifications, experience and background. The company is to strive for equal gender distribution on the board." Swedish companies are then invited to commit, on a voluntary basis, to apply the above principle. While they do not face any sanction should they fail to follow it, shareholders and the media have the right to ask why they did not, a principle known as "Comply or Explain". In 2012 women made up 25\% of Swedish largest companies board members, well above the European average of $15.3 \%$, yet below Norway's $36 \%$ (Figure 35), making Sweden the country with the third highest percentage of females board members (Finland being second). A number of other European countries are in the process of implementing quotas, ranging from 30 to $40 \%$, or implementing a system similar to Sweden's.

Data compiled in the 2014 Schilling Report on the 100 largest Swiss companies show that there were 50 women on their executive boards in $2013,6 \%$ of the 852 total board members. Similarly, $9 \%$ of the new board members were women. Only $50 \%$ of those women were Swiss citizens, and $70 \%$ of the newly appointed females in 2013 were foreigners. Not surprisingly $88 \%$ of all female executive boards members had a university degree, highlighting the role of higher education in helping women reach the top. The proportion of female CEOs was much lower at $3 \%$. A corporate governance code should be implemented to establish gender goals to increase the number of women in senior management and company boards. While progress remains to be made in the business sector, via promoting female leadership role models for instance, Swiss women have gained an important role in Swiss political life both in terms of absolute achievements and progress. While in 1983 no woman sat on the Federal Council and there were few elsewhere, today three of the seven current Federal Councillors are women. Progress has been significant in other representative and executive bodies too, though there has been some stagnation in the past 5-10 years (Figure 36). Gender diversity in public institutions is particularly crucial given that these institutions create rules, make decisions and influence the allocation of resources. Greater diversity can provide a balanced perspective, thus enabling an inclusive approach to policy making and service delivery (OECD, 2014). 
Figure 36. Swiss women have increased their presence in political institutions

Share of women in representatives and executive bodies

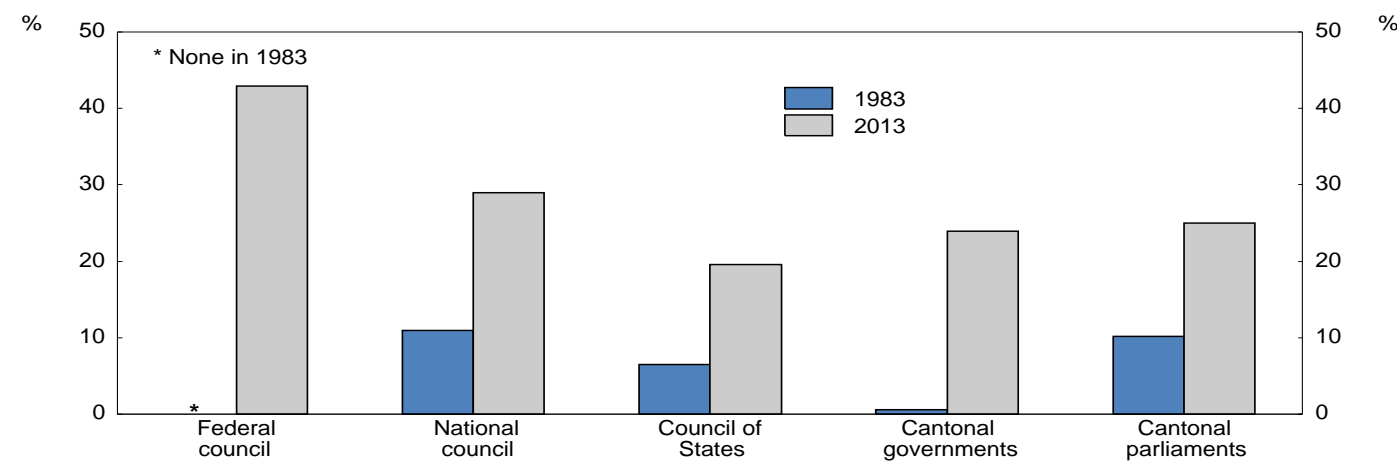

Source: FSO, Cantonal election statistics.

\section{The potential for women entrepreneurs}

Swiss women are well positioned to develop and succeed in entrepreneurial ventures. First, as noted earlier, they perform very well at school and now constitute of majority of young graduates with highly valued professional skills. Second, the Swiss economy enjoys a dense network of successful medium-size companies that can support start-ups, both as mentors and potential customers, especially once women entrepreneurs gain a toehold.

Despite these assets, and in line with what is observed in other OECD countries, women are underrepresented as entrepreneurs in Switzerland, with no improvement in sight. Perhaps one explanation is preferences. When asked about their preferred choice, only 33\% of Swiss (OECD: $31.5 \%$ ) women would prefer self-employment over dependent employee status, versus $44.8 \%$ for Swiss men (OECD: 43.5\%). One additional reason could be the low level of government support in Switzerland for female entrepreneurs. According to a 2003 study conducted by the Global Entrepreneurship Monitor, Switzerland ranked second to last on a composite support index that combines measures of social infrastructures for women with family, society's view on female entrepreneurs and chances of success.

Despite those hurdles Swiss female entrepreneurs perform better than their EU counterparts on a number of criteria. For instance 3.4\% of Swiss women are employers, above the EU27 average of $2.4 \%$ (8.6\% and $6.2 \%$ for males, respectively; Figure 37). Looking at the three-year survival rate of male and female-owned companies, Switzerland is the only country in the sample that shows a higher survival rate for the latter (Figure 38). This good performance, however, may be due to the fact that women generally set up smaller companies in less risky sectors like tutoring or personal care services (OECD, 2012d). Additional progress could be made by fostering a positive image of entrepreneurship amongst women, promoting entrepreneurship networks (though not gender-specific, cf. Ferrant, 2012), mentoring and coaching programmes, as well as integrating a gender dimension in business surveys of SMEs in order to better understand barriers to entrepreneurship among women. Finally, introducing courses on how to start a business in upper secondary school could further alleviate some of the fears associated with setting up a business. 
Figure 37. Share of women and men employers, 2011

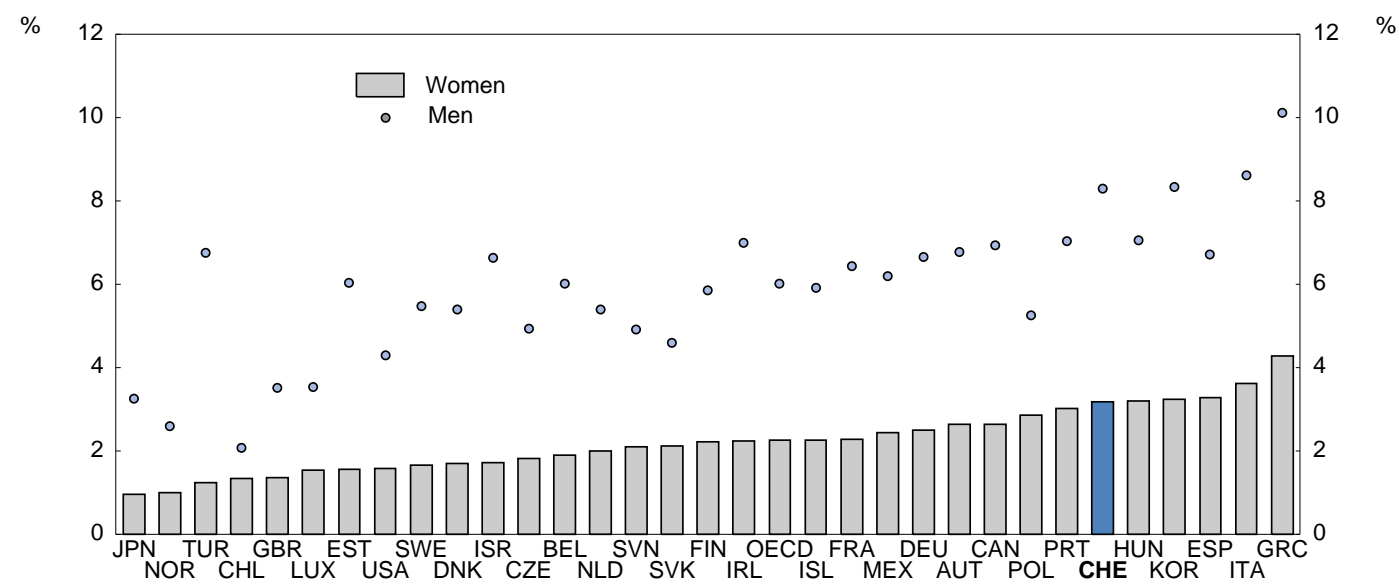

Source: OECD, Entrepreneurship at a Glance 2013.

Figure 38. Three-year survival rate of men and women-owned enterprises 2010

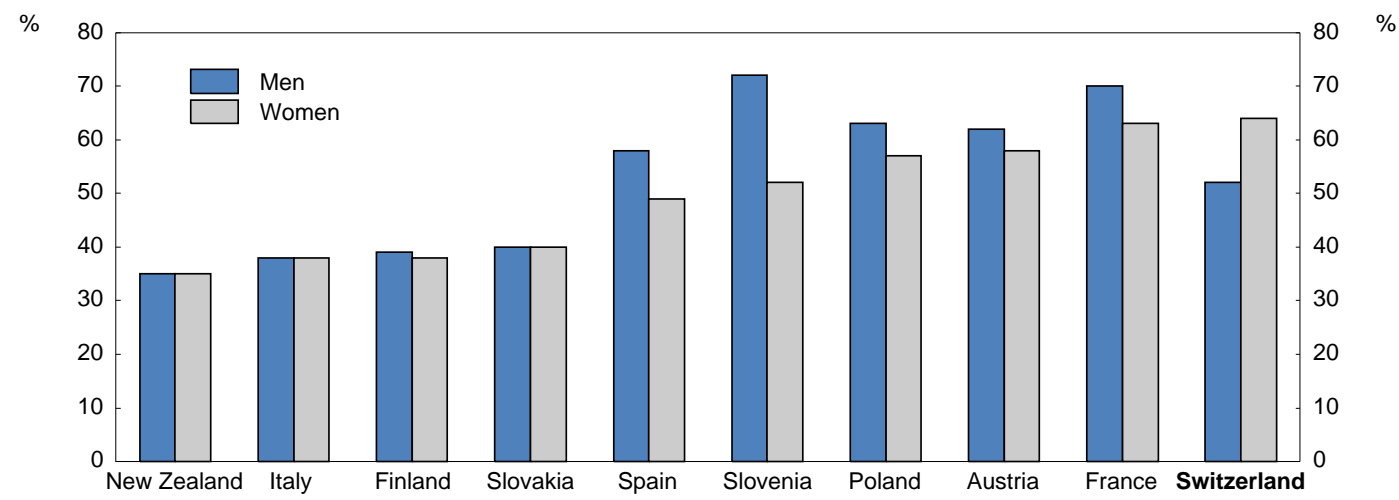

Source: OECD (2012d), Entrepreneurship at a Glance 2012.

Regarding the type of activity, a majority of the new businesses set up by women belong to classic female fields (Figure 39). More than $30 \%$ of new companies in the areas of social work, teaching, arts, entertainment and health (a majority in this case) are started by women only, and a majority of them including those set up jointly with one or several male business partners. In almost all other fields a majority of new companies are started by men only. In addition to gender-typical choices of education, these statistics reflect the greater proportion of young women opting for general/academic studies, in contrast to male youths who tend to choose VET training and applied professions such as construction and engineering. It follows that business choices too remain gender-specific in Switzerland. 
Figure 39. New companies by owner's gender and sector, 2011

Per cent

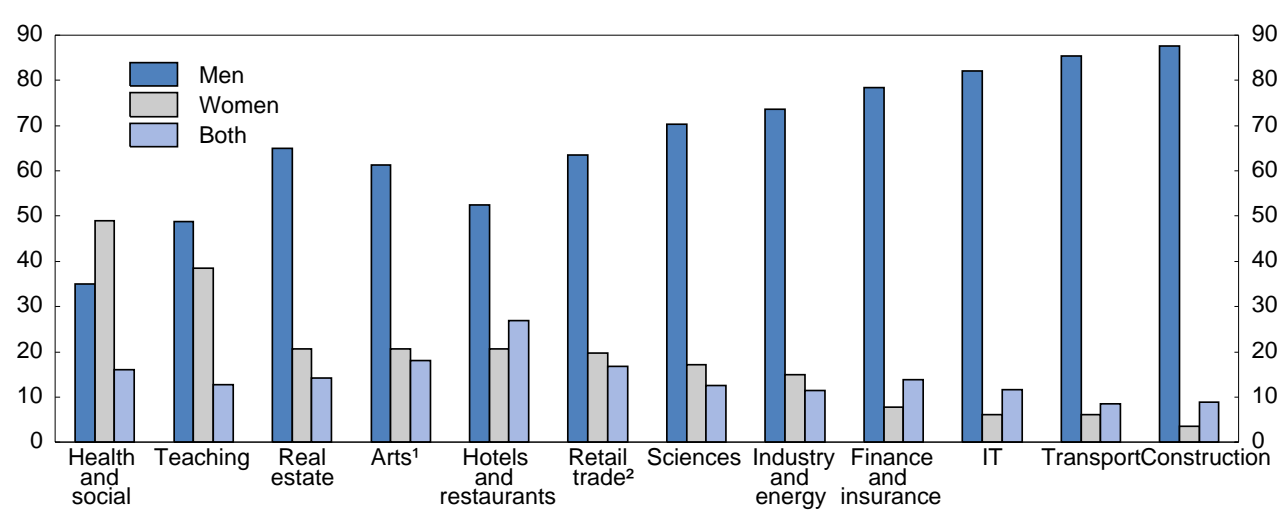

1. Including entertainment

2. Including reparation

Source: FSO, Business demography statistics.

Box 13. Recommendations for removing the glass ceiling and encouraging entrepreneurship among women

- Implement a corporate governance code establishing gender goals to increase women in senior management.

- Increase the proportion of women on company boards by setting ambitious targets combined with the "Comply or Explain" practice or by setting quotas.

- $\quad$ Foster a positive image of entrepreneurship amongst women by allowing successful women entrepreneurs to tour secondary and tertiary educational institutions to explain the rewards and advantages of setting up one's own business, especially given women's preference for flexible work solutions.

- $\quad$ At the cantonal level promote development of women entrepreneurship networks, and support mentoring and coaching programmes for aspiring young women entrepreneurs.

- Introduce courses in upper secondary school on how to start a business.

- Always integrate a gender dimension in business surveys of SMEs to better understand barriers to entrepreneurship among women.

\section{Bibliography}

Adams, R. and D. Ferreira (2009), "Women in the Boardroom and Their Impact on Governance and Performance", Journal of Financial Economics, Vol. 94, No. 2, pp. 291-309.

Adams, R. and P. Funk (2012), “Beyond the Glass Ceiling: Does Gender Matter?", Management Science, Vol. 58, No. 2, pp. 219-35, February. 
Ahern, K. and A. Dittmar (2012), "The Changing of the Boards: The Impact of Firm Valuation of Mandated Female Board Representation", The Quarterly Journal of Economics, Vol. 127, No. 1, pp. 137-97.

Becker, G. (1957), The Economics of Discrimination, The University of Chicago Press, Chicago.

Bergman, M., S. Hupka-Brunner and S. Kanji (2012), "Gender Differences in the Transition from Secondary to Post-secondary Education: The Case of Switzerland", Background paper for the $\mathrm{OECD}$ Gender Initiative.

Black, E. and P. Strahan (2001), "The Division of Spoils: Rent-Sharing and Discrimination in a Regulatory Industry", The American Economic Review, Vol. 91, No. 4, pp. 814-831.

Böhren, O. and R. Ström (2005), "The Value-Creating Board: Theory and Evidence”, Research Report, No. 8/2005, Department of Financial Economics, Norwegian School of Management, Oslo.

Brown, A.H., D.L. Brown and V. Anatasopoulos (2002), "Women on Boards. Not Just the Right Thing... But the Bright Thing", Conference Board of Canada Report, May.

Carter, D., B. Simkins and G. Simpson (2003), "Corporate Governance, Board Diversity and Firm Value", Financial Review, Vol. 38, No. 1, pp. 33-53.

Catalyst (2008), Advancing Women Leaders: The Connection Between Women Board Directors and Women Corporate Officers, New York.

Coles, J., N. Daniel, and L. Naveen (2008), “Boards: Does One Size Fit All?”, Journal of Financial Economics, Vol. 87, pp. 329-56.

Credit Suisse (2012), “Gender Diversity and Corporate Governance”, Research Institute, Thought leadership from Credit Suisse Research and the world's foremost experts.

Egon Zehnder International (2012), Global Board Index, European Board Diversity Analysis 2012.

Fagnani, J. (2002), "Why do French Women Have More Children Than German Women? Family policies and attitudes towards child care outside the home", Community, Work and Family, Vol. 5, No. 1, pp. 103-19.

Federal Statistical Office (FSO) (2013a), "Maturités et passage vers les hautes écoles", Education et Science 15, Neuchâtel.

Federal Statistical Office (FSO) (2013b), "Vers l'égalité entre femmes et hommes", Situation Economique et Sociale de la Population, Neuchâtel.

Ferrant, G. (2012), "Les réseaux sur le marché du travail sud-africain. Une efficacité inégale selon le sexe et l'ethnie", Revue économique, Vol. 63, No. 3, pp. 465-74.

Hellerstein, J., D. Neumark and K. Troske (2002), "Market Forces and Sex Discrimination”, Journal of Human Resources, University of Wisconsin Press, Vol. 37(2), pp. 353-380.

Imdorf, C., S. Sacchi, K. Wohlgemuth, S. Cortesi and A. Schoch (2013), "How Education Systems Promote Gender-Typical School-to-Work Transitions. The Case of Cantonal Educations Systems in Switzerland", University of Basel, manuscript. 
Kamerman, S. and P. Moss (2009), The Politics of Parental Leave Policy, Policy Press, Bristol.

Lee, P. and E. James (2007), "She'-E-Os: Gender Effects and Investor Reactions to the Announcements of Top Executive Appointments”, Strategic Management Journal, Vol. 28, No. 3, pp. 227-41.

Lewis, J. (2009), Work-Family Balances, Gender and Policy, Edward Elgar, Cheltenham, United Kingdom.

Linck, J., J. Netter and T. Yang (2008), "The Determinants of Board Structure", Journal of Financial Economics, Vol. 87, pp. 308-28.

Lovász, A. (2008), "Competition and the Gender Wage Gap: New Evidence from Transitional Linked Employer-Employee Data", Central European University, manuscript.

Marinova, J., J. Plantenga and C. Remery (2010), "Gender Diversity and Firm Performance: Evidence and Dutch and Danish Boardrooms", Discussion Paper Series, No. 10-03, Tjalling C. Koopmans Research Institute, Utrecht.

McKinsey\&Company (2007), Women Matter: Gender Diversity, a Corporate Performance Driver, Paris.

McKinsey\&Company (2010), Women at the top of corporations: making it happen, Paris.

Mueller, S., W. Danhong, M. Fox, B. Yeo, J. Sepulcre, M. Sabuncu, R. Shafee, J. Lu and H. Liu (2013), "Individual Variability in Functional Connectivity Architecture of the Human Brain", Neuron, Vol. 77, No. 3.

Müller, F., B. Gysin and A. Balthasar (2010), "Evaluation Pilotprojekt Betreuungsgutscheine in der Gemeinde Horw", Interface.

Nielsen, S. and M. Huse (2010), "The Contribution of Women on Boards of Directors: Going Beyond the Surface”, Corporate Governance: An International Review, Vol. 18, No. 2, pp. 136-48.

NOGA (2008). Nomenclature Générale des Activités Économiques, Neuchâtel.

OECD (2009), Equally prepared for life? How 15 year-old boys and girls perform in school, OECD Publishing.

OECD (2012a), Closing the Gender Gap: Act Now, OECD Publishing.

OECD (2012b), Gender Initiative: Gender Equality in Education, Employment and Entrepreneurship, OECD Publishing.

OECD (2012c), Education at a Glance, OECD Publishing.

OECD (2012d), Entrepreneurship at a Glance, OECD Publishing.

OECD (2013), Draft Recommendation of the Council on Gender Equality in Education, Employment and Entrepreneurship, Meeting of the OECD council at ministerial level.

OECD (2014), Women, Government and Policy Making in OECD Countries. Fostering Diversity for Inclusive Growth, OECD Publishing 
OFAS (2012), “Wirkungsanalyse Mutterschaftsentschädigung”, research report.

Randøy, T., S. Thomsen and L. Oxelheim (2006), “A Nordic Perspective on Corporate Board Diversity”, Nordic Innovation Centre Project No. 05030, Oslo.

Rhode, L.D. and K.A. Packel (2010). "Diversity on Corporate Boards: How Much Difference does Difference Make?", Stanford Law School, Palo Alto, California.

Rose, C. (2007), "Does Female Board Representation Influence Firm Performance? The Danish Evidence", Corporate Governance: An International Review, Vol. 15, No. 2, pp. 404-13.

Salvi Del Pero, A. and A. Bytchkova (2013), “A Bird's Eye View of Gender Differences in Education in OECD Countries", OECD Social, Employment and Migration Working Papers 148, OECD Publishing.

Schilling Report (2014), Transparency at the Top. The Executive and Supervisory Boards of the one 100 largest Swiss companies, Zurich.

SECO (2007), "Familienergänzende Kinderbetreuung und Erwerbsverhalten von Haushalten mit Kindern", Vereinbarkeit von Beruf und Familie Nr. 3, Istituto di Microeconomia e Economia Pubblica (MecoP), Università della Svizzera italiana INFRAS, Forschung und Beratung, Zürich.

SECO (2012), «Effets du programme conjoncturel sous l'angle de l'égalité des sexes », Rapport du 16 mai 2012 faisant suite au postulat 09.3297, Groupe des Verts.

Strub, S. and D. Stocker (2008), “Analyze der Lohne von Frauen und Manner anhand der Lohnstrukturerhebung 2008", Technical Report, Buro fur Arbeits- und Sozialpolitishe Studien BASS AG, Bern.

Terjesen, S., R. Sealy and V. Singh (2009), "Women Directors on Corporate Boards: A Review and Research Agenda", Corporate Governance: An International Review, Vol. 17, No. 3, pp. 320-37.

Veenhoven, R. (2011), "Social Development and Happiness in Nations 1990-2010", Presentation at Conference "Taking Stock: Measuring Social Development", International Institute of Social Studies, 14-15 December.

Veenhoven, R. (2012), World Database of Happiness, Erasmus Universiteit, Rotterdam.

World Economic Forum (2013), The Global Gender Gap Report 2013, Geneva. 
ECO/WKP(2014)40

\section{WORKING PAPERS}

The full series of Economics Department Working Papers can be consulted at www.oecd.org/eco/workingpapers/

1143. Overcoming skills shortages in Canada

(July 2014) by David Carey

Combler les pénuries de compétences au Canada

(Juillet 2014) par David Carey

1142. Trade patterns in the 2060 world economy

(July 2014) by Jean Chateau, Lionel Fontagné, Jean Fouré, Åsa Johansson and Eduardo Olaberria

1141. The Demand for Skills 1995-2008: A global chain perspective

(July 2014) by Bart Los, Marcel P. Timmer and Gaaitzen J. De Vries

1140. International migration: The relationship with economic and policy factors in the home and destination country

(July 2014) by Ben Westmore

1136. Long-term patterns of trade and specialisation

(July 2014) by Asa Johansson and Eduardo Olaberria

1135. Consequences of climate change damages for economic growth - a dynamic quantitative assessment

(July 2014) by Rob Dellink, Elisa Lanzi, Jean Chateau, Francesco Bosello, Ramiro Parrado and Kelly de Bruin

1134. Comparing the robustness of PAYG pension schemes

(July 2014) by Falilou Fall

1133. Overcoming vulnerabilities of pension systems

(July 2014) by Falilou Fall and Debbie Bloch

1132. Overcoming vulnerabilities of health care systems

(July 2014) by Mauro Pisu

1131. Overcoming vulnerability of unemployment insurance schemes

(July 2014) by Jon Pareliussen

1130. Vulnerability of social institutions: Lessons from the recent crisis and historical episodes

(July 2014) by Falilou Fall, Mauro Pisu, Jon Pareliussen and Debbie Bloch

1129. An update of the OECD international trade equations

(June 2014) by Myriam Morin and Cyrille Schwellnus

1128. What explains the volume and composition of trade? Industrial evidence from a panel of countries

(June 2014) by Asa Johansson, Przemyslaw Kowalski, Eduardo Olaberria and Dario Pellegrino

1127. Do resources flow to patenting firms: cross-country evidence from firm level data 
(June 2014) by Dan Andrews, Chiara Criscuolo and Carlo Menon

1126. Macroprudential policy tools in Norway: Strengthening financial system resilience (June 2014) by Yosuke Jin, Patrick Lenain and Paul O’Brien

1125. Strengthening competition in Poland

(June 2014) by Balász Égert and Antoine Goujard

1124. Making the labour market work better in Poland

(June 2014) by Hervé Boulhol

1123. Enhancing competition and the business environment in Hungary

(June 2014) by Alvaro Pina

1122. Tackling labour mismatches and promoting mobility in Hungary

(June 2014) by Stéphane Sorbe

1121. Local public finances and municipal reform in Finland

(June 2014) by Christophe André and Clara Garcia

1120. The economic consequences of ageing: the case of Finland

(June 2014) by Christine de la Maisonneuve, Christophe André, Clara Garcia and Vincent Koen

1119. Making the most of skills in Denmark

(June 2014) by Stéphanie Jamet and Vincent Koen

1118. Trade specialisation and policies to foster competition and innovation in Denmark (June 2014) by Müge Adalet McGowan

1117. Policies for making the Chilean labour market more inclusive (June 2014) by Aida Caldera Sanchez

1116. Spillover effects from exiting highly expansionary monetary policies

(May 2014) by Łukasz Rawdanowicz, Romain Bouis, Jérôme Brezillon, Ane Kathrine Christensen and Kei-Ichiro Inaba

1115. Economic policies and microeconomic stability: A literature review and some empirics (April 2014) by Paula Garda and Volker Ziemann

1114. How to improve Israel's health-care system

(April 2014) by Philip Hemmings

1113. How to improve taxes and transfers in Israel

(April 2014) by Philip Hemmings

1112. New evidence on the determinants of industrial specialisation

(April 2014) by Asa Johansson and Eduardo Olaberria 